\title{
Parent-related mechanisms underlying the social gradient of childhood overweight and obesity: A systematic review
}

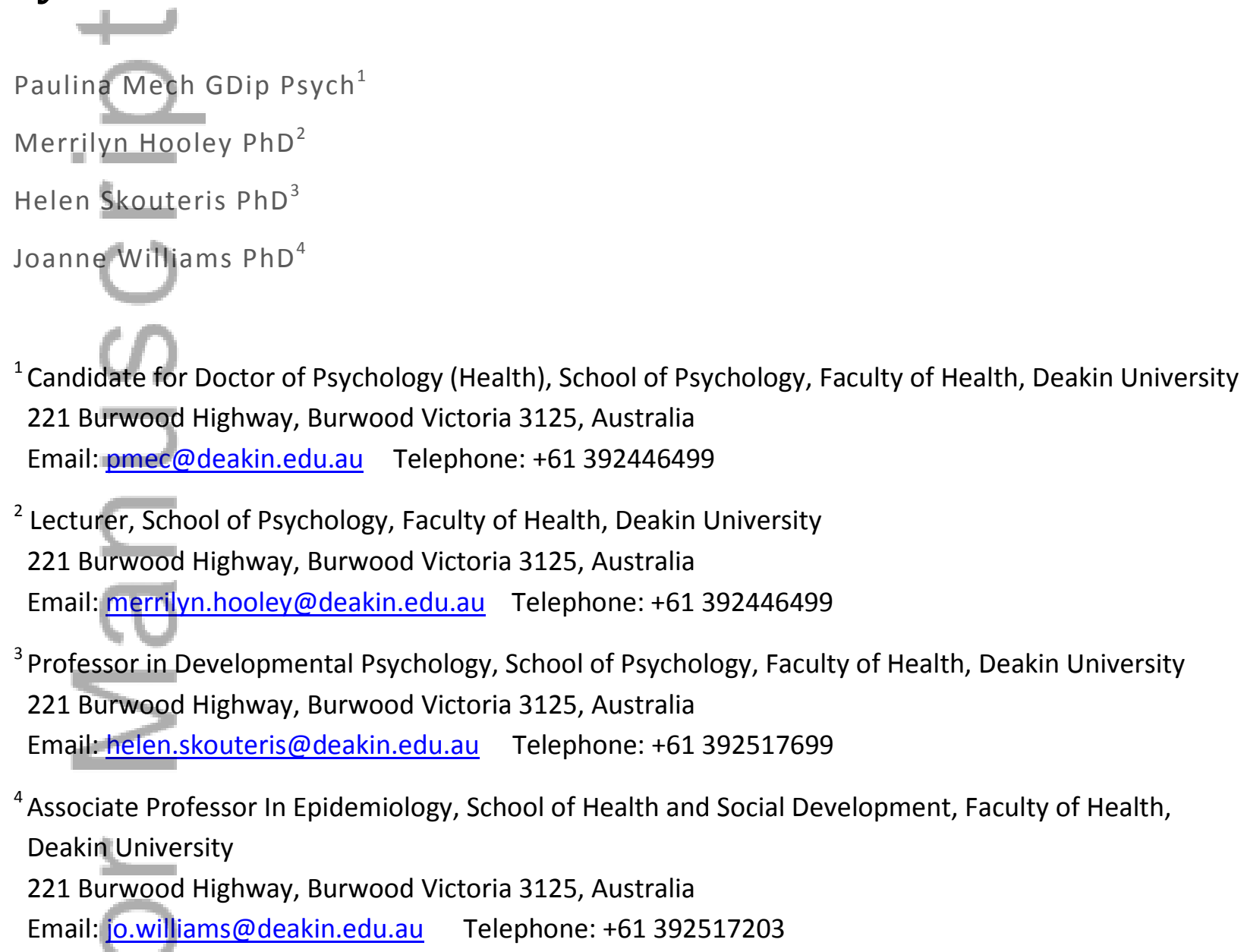

This is the author manuscript accepted for publication and has undergone full peer review but has not been through the copyediting, typesetting, pagination and proofreading process, which may lead to differences between this version and the Version of Record. Please cite this article as doi: 10.1111/cch.12356

This article is protected by copyright. All rights reserved. 
Word count: 4620

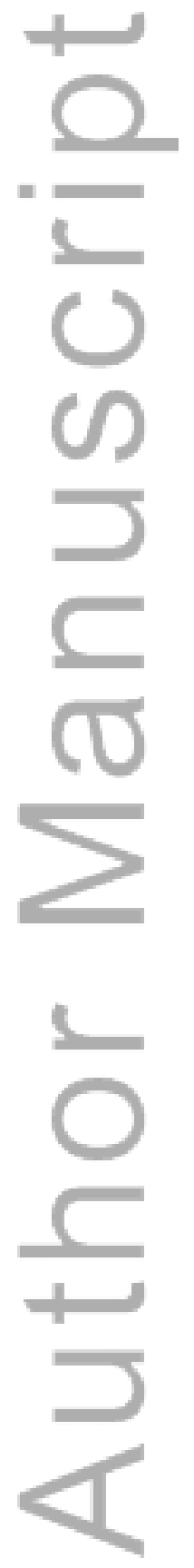

This article is protected by copyright. All rights reserved. 


\begin{abstract}
Background Low socioeconomic status (SES) is a significant risk factor for childhood overweight and obesity (COWOB) in high income countries. Parents to young children buffer and accentuate social and cultural influences, and are central to the development of this disease. An understanding of the parent-related mechanisms that underlie the SES - COWOB relationship is needed to improve the efficacy of prevention and intervention efforts.

in
\end{abstract}

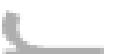

Objective A systematic review of relevant literature was conducted to investigate the mechanisms by which levels of SES (low, middle and high) are associated to COWOB, by exploring mediation and interaction effects.

Method Six electronic databases were searched yielding 5155 initial records, once duplicates were removed. Studies were included if they investigated COWOB, SES, parent-related factors, and the multivariate relationship between these factors. Thirty studies were included. Factors found to be mediating the SES-COWOB relationship or interacting with SES to influence COWOB were categorised according to an ecological systems framework, at child-, parent-, household- and socialsystem level factors.

Results High parent BMI, ethnicity, child-care attendance, high TV time (mother and child), breastfeeding (early weening), food intake behaviours and low birth weight potentially mediate the relationship between SES and COWOB. Different risk factors for COWOB in different SES groups were found. For low SES families, parental obesity and maternal depressive symptoms were strong risk factors for COWOB; whereas long maternal working hours and a permissive parenting style were risk factors for higher SES families. None of the studies investigated parental psychological attributes such as attitudes, beliefs, self-esteem, etc. as potential mechanisms/risk factors.

This article is protected by copyright. All rights reserved. 
Conclusions Families from different SES groups have different risk and protective factors for COWOB. Prevention and intervention efforts may have improved efficacy if they are tailored to address specific risk factors within SES.

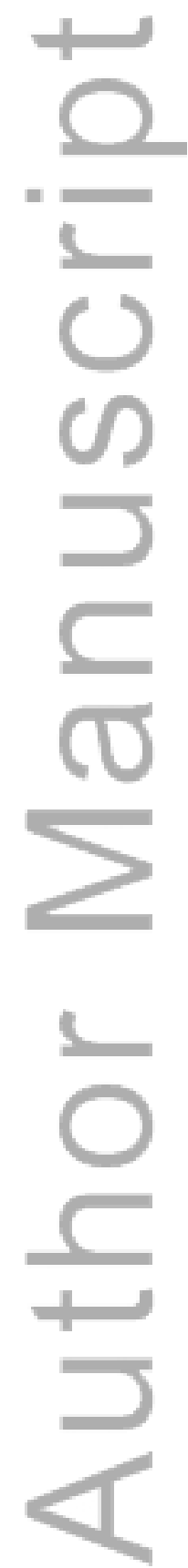

This article is protected by copyright. All rights reserved. 
Childhood overweight and obesity (COWOB) has reached epidemic proportions around the world (World Health Organization, 2013). Attempts to reduce COWOB have ranged from individual interventions (e.g., behavioural counselling) (Campbell \& Hesketh, 2007) to public policies (e.g., environmental changes within schools) (Bleich et al., 2013). However, these programs have had only moderate success in reducing rates (Bleich et al., 2013; Campbell \& Hesketh, 2007). Lack of success $=$

could be due to a narrowed focus on factors identified through cross-sectional bivariate studies exploring the disease and its risk factors (Boonpleng et al., 2013; Cockrell \& Foster, 2013; Davison \& Birch, 2001). A broader approach exploring the multiple pathways towards the development of COWOB might better inform tailored interventions (Brown et al., 2010; Cockrell \& Foster, 2013) and subsequently improve their efficacy.

One of the most commonly identified factors associated with COWOB, and indeed many other health problems, is socioeconomic status (SES) (Shrewsbury \& Wardle, 2008; Sobal \& (a) Stunkard, 1989); consequently, many researchers control for SES rather than examine it (Adler et al., 1994). SES can be considered to reflect the context in which a child lives; it represents their social standing, ability to participate in society and access to material and social resources (American Psychological Association, 2013; Australian Bureau of Statistics, 2006). However, the mechanisms through which SES has its influence on child weight are still unclear (Shrewsbury \& Wardle, 2008; Sobal \& Stunkard, 1989).

In 1989, Sobal and Stunkard published findings of their review of 144 studies exploring the relationship between SES and overweight and obesity in adults and children; the studies were published between 1933 and 1982. Approximately equal numbers of studies found a negative association between SES and COWOB for girls $(40 \% ; n=13)$ and boys $(32 \% ; n=11)$. They concluded that the relationship in high income countries is complex and required further exploration (Sobal \& Stunkard, 1989). Shrewsbury and Wardle conducted a subsequent review of 45 cross-sectional 
studies published between 1990 and 2005 in high income countries only (Shrewsbury \& Wardle, 2008). Forty-two percent of studies $(n=19)$ reported a negative association between SES and COWOB. Shrewsbury and Wardle recommended further research to "understand the mechanism by which parental education and other indicators of SES independently and collectively influence [child feeding and physical activity]" (Shrewsbury \& Wardle, 2008, p. 282). Zarnowiecki, Dollman and Parletta (2014) conducted a systematic review of the associations between predictors of children's dietary intake and SES. Predictors of children's dietary intake were found to vary among different SES groups (Zarnowiecki et al., 2014). Given that weight status in pre-adolescence (up to approximately 8-years-old) is a reliable predictor of weight status in adolescence and adulthood (Guo et al., 2002; Whitaker et al., 1997) identification and modification of factors influencing early childhood weight gain (i.e., in children to eight years of age) may have the greatest impact in reducing overweight.

Bronfenbrenner's Ecological Systems Theory (EST) (Bronfenbrenner, 1979) is useful to conceptualise the factors that may mediate the relationship between SES and COWOB, or interact with SES to influence COWOB. The theory situates the child at the centre of nested ecological systems, where bi-directional interactions occur between systems, and changes in one system can directly or indirectly affect child outcomes (Bronfenbrenner, 1979). Four systems are proposed based on research purporting that families/parents buffer and accentuate social and cultural influences, and are central to the development of COWOB (Davison et al., 2012). These systems are: the child-system (the immediate factors that contribute to child weight status), the parent- system (factors related to the important role of parents as the child's primary socialising agent), the household-system (factors that represent the climate within which parent-child interactions take place, e.g. migrant-status) and the social-system (SES), collectively referred to as socio-ecological factors. The bi-directional interactions that occur between systems indicate that all systems are important but the parent system is of greatest interest because of its potential to enact change. 
The overall aim of the present systematic review was to explore the parent-related mechanisms by which categories of SES (low, middle and high) are associated with COWOB in children to age 8 years, and to frame this within EST (i.e., to include available child, household and social system factors within this literature). To our knowledge, no previous systematic review has focused on identifying and understanding the associations between COWOB and SES category. The scope of the review is limited to multifactorial analyses (both cross-sectional and prospective designs) in order to explore possible mediation and interaction effects of the relationship between SES categories and COWOB. Where there was evidence to support directionality (i.e., that SES influenced the association between СOWOB and other factors or that other factors influenced the association between COWOB and SES), the term moderation was tentatively used to describe the finding.

The research questions that informed this systematic review were:

1. What do studies reveal about potential mediators of the relationship between SES and COWOB?

2. What do studies reveal about the factors that interact with SES to influence COWOB?

3. What are the relative strengths and limitations of studies designed to understand the effect of SES on COWOB and what recommendations can be made for future research?

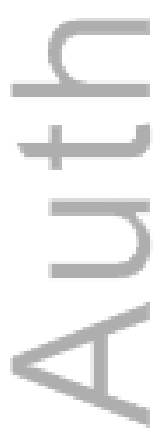

\section{Method}

Six electronic databases were searched: Psycinfo, Medline, CINAHL, Academic Search Complete, Scopus and Web of Knowledge. A lateral search of reference lists of included papers was also undertaken.

This article is protected by copyright. All rights reserved. 


\section{Search Strategy}

The search was conducted in February 2016, with no restrictions on the publication date for articles. The search terms included word variations of three key research areas: parental/parenting factors, SES and COWOB. Search strings were created by combining related terms (in the columns) using OR, and connecting concepts using AND (see Table 1). Where available, subject heading terms were included in the search strings, however not all databases contained this option.

-

Inclusion criteria

Figure 1 illustrates the search strategy, inclusion and exclusion criteria at each step and number of studies included. In brief, the inclusion criteria required that studies involved children $0-8$ years and from high income countries (as established by the International Monetary Fund classification system) (International Monetary Fund, 2013; Nielsen, 2011). These studies must have investigated COWOB, SES, parent-related/socio-ecological factors, and the multivariate relationship between these factors. To acknowledge the bidirectional influences of social, household, child and parenting/parental factors on COWOB, factors reflecting all four socio-ecological levels reported within the included studies are also summarised in this paper. However it was not the purpose of this paper to provide a comprehensive review of the child, household and social system factors. A total of 28 studies from the initial search and two studies from a lateral search were included in the review (with a total of 30), and 5127 studies were excluded. The earliest included study was published in 2003. The socio-ecological factors were assigned to the four systems according to the definitions stated earlier and where there was uncertainty surrounding the allocation to a system, assignment was discussed by $\mathrm{PM}$ and $\mathrm{MH}$ to reach consensus.

\section{Quality assessment of scientific evidence}

In accordance with the PRISMA guidelines (Moher et al., 2009), each of the studies that met the inclusion criteria was subjected to a critical evaluation process which assessed the quality of the 
evidence and risk of bias. A scoring system adapted from Cohen et al.'s (Cohen et al., 2013) review was used to assess bias, as determined by sample size, response rate, characteristics of the study population, and methodology (measurement, statistical analyses and interpretation methods). A detailed explanation of the scoring system and allocation of points can be found in the supplement table 1. The highest possible score was eight. In addition to this, an assessment of mediation was conducted. Determining mediation can be a challenging task as the researcher must infer mediation from observations using theoretical reasoning and/or empirical and statistical data (MacKinnon et al., 2007). In order to assess the confidence of this inference, mediation was assessed according to Baron and Kenny's (1986) "causal steps approach". Studies were scored against the four criteria: 1) A significant relation of the independent variable (IV) to the dependent variable (DV) is required; 2) A significant relation of the IV to the hypothesised mediator variable (MV) is required; 3 ) The MV must be significantly related to the DV when both the IV and $M V$ are predictors of the $D V, 4)$ The coefficient relating the IV to the DV must be larger (in absolute value) than the coefficient relating the IV to the DV in the regression model with both the IV and MV in it. Each criteria was appointed a score of 0 if the information was not reported at all, 0.5 if the information was reported but without numerical evidence or 1 if all information was reported. Hypothesised MVs with scores of 3-4 were taken to represent strong evidence of a mediation effect, MVs with scores of 2-3 were considered to represent moderate evidence of a mediation effect and MVs with scores of less than 2 represent weak evidence.

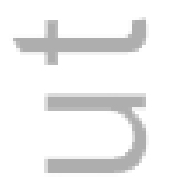

\section{Results}

Table 2 summarises information about each study, including the sample demographics, sample size, study design and measures. The 30 included studies were conducted in North America ( $n=14)$, Europe $(n=10)$, Australia $(n=4)$, and Asia $(n=1)$, including one study with samples from both North America and Europe. The studies were a mixture of cross-sectional $(n=15)$, longitudinal 
$(n=12)$, and mixed designs $(n=3)$. The assessment of study quality suggested low risk of bias in all studies and so all studies were included in the review (see Supplementary Table 1).

Child weight status was classified according to the International Obesity Taskforce (IOTF)(Cole et al., 2000) standards, US Centres for Disease Control (CDC)(Centers for Disease Control Prevention) standards, and non-standardised country-specific BMI-for-age reference charts; two studies reported both IOTF and CDC standards and one did not report the classification system. In Maternal education was the most commonly used proxy measure for SES ( $n=19)$, followed by household income $(n=16)$, composite score $(n=3)$ and occupational prestige $(n=2)$; with some studies exploring multiple proxies within their studies. Twenty studies were assessed for mediation effects, their scores are reported in tables 3 and 4.

Child-system factors. Table 3 presents the fourteen studies that explored child-system factors; children's birth weight, TV watching, eating behaviours and breastfeeding in relation to their influences on the SES-COWOB relationship. Low birth weight was investigated in 10 studies; seven studies reported evidence of varying strengths to suggest low birth weight as a mediator of the SESCOWOB relationship (Balistreri \& Van Hook, 2011; Cho et al., 2009; Demment, 2014; Gibbs \& Forste, 2014; Klebanov et al., 2014; Layte et al., 2014; Strauss \& Knight, 1999) while three studies reported findings with varying strengths of evidence for no mediation (Beyerlein, 2010; Gopinath, 2012; Jansen et al., 2013). TV viewing was investigated in five studies and while evidence of a mediation effect was found in all five studies, the quality of the mediation analyses were weak (Beyerlein, 2010; Cho et al., 2009; Dubois, M., 2006; Ebenegger et al., 2011; Moraeus, 2012; Veldhuis et al., 2013). The mediating influence of children's eating behaviours were also unclear as two studies reported strong evidence to suggest breakfast omission had a mediating influence (Moraeus, 2012; Veldhuis et al., 2013), while another two studies reported insufficient information to determine whether mediation had occurred or not (Dubois et al., 2006; Ebenegger et al., 2011)). Finally, breastfeeding (early weening) was investigated in three studies and all found support for a 
mediation effect; two reported strong evidence (Gibbs \& Forste, 2014; Layte et al., 2014), while the third contained weak evidence (Beyerlein, 2010).

In addition to mediation effects, one study explored possible interaction effects involving child sex, SES and COWOB (Balistreri \& Van Hook, 2011). Child sex moderated the relationship between SES and child weight trajectories. Both low levels of parental education and baseline income were predictors of preschool girls being 'always overweight' or 'gradual overweight' (i.e.,

gradualincrease in weight) (Balistreri \& Van Hook, 2011). In preschool boys, parental education was the only predictor of gradual increase in weight, but both parental education and baseline income were weak predictors of 'always overweight' (Balistreri \& Van Hook, 2011).

Parent-system factors. The fourteen studies that explored parent-system factors are presented within Table 4. There was evidence to suggest that parent weight status and maternal TV viewing potentially mediate the SES-COWOB relationship, ambivalent evidence for mother's age, and there was evidence to suggest that smoking during pregnancy and currently, feeding styles, depressive symptoms and alcohol consumption do not mediate the SES COWOB relationship. Results involving high parent weight status strongly supported it as a mediator of the SES-COWOB relationship (Bingham, 2013; Demment, 2014; Dubois et al., 2005; Gibbs \& Forste, 2014; Hancock, 2014; Jansen et al., 2013; Layte et al., 2014; Moraeus, 2012; Veldhuis et al., 2013; Waters et al., 2014). Only one study reported results that potentially reject parent weight status as a mediator (Dubois \& Girard, 2006). High duration of maternal TV viewing was investigated in one study and had moderate evidence to suggest it was a mediator also (Veldhuis et al., 2013). There was contradictory evidence for the influence of mother's age as one study indicated potential mediation (Gibbs \& Forste, 2014) whilst another rejected this (Layte et al., 2014). Smoking during pregnancy was investigated in three studies; there was weak evidence to suggest smoking during pregnancy mediated the SES-COWOB relationship (Beyerlein, 2010), with stronger evidence to suggest that it did not mediate the relationship (Dubois \& Girard, 2006; Gopinath, 2012). Factors that did not 
mediate the SES-COWOB relationship were current maternal smoking (Gibbs \& Forste, 2014), parental feeding styles (Wehrly et al., 2014), depressive symptoms (Gibbs \& Forste, 2014) and alcohol consumption (Layte et al., 2014); these were all tested in one study each.

Three variables that interacted with SES were identified. In low SES families there was evidence that parental weight status (healthy-weight/obese) (Semmler et al., Ashcroft et al., 2009) and presence of maternal depressive symptoms (Morrissey \& Dagher, 2014) were important risk factors. SES appeared to moderate the prospective association between parental weight status and children's BMI (Semmler et al., 2009). Collapsed across SES, children with healthy-weight parents showed similar changes in BMI regardless of SES, and children of obese parents showed a significant increase in BMI over a seven year period compared to children of healthy weight parents. However children of obese parents in low SES families showed significantly greater BMI increase compared to their counterparts in high SES families (Semmler et al., 2009). Having an obese parent was deleterious to the weight of children, particularly in low SES families where maternal depressive symptoms were also found to have greater influence. Maternal depressive symptoms were associated with COWOB in families of low and high SES but longer duration of maternal depressive symptoms accounted for more variance in low SES families than high (Morrissey \& Dagher, 2014). Note that these results were found in single high and low quality studies and require replication.

Only one type of factor was identified as being an important risk factor in higher SES families, parenting style. Four studies investigated the interaction between parenting styles, SES and child weight status (Kakinami, 2015; Lane et al., 2013; Rodenburg, 2011; Topham et al., 2010). The odds of children being obese increased over threefold with increasing permissive parenting style in high SES families (Topham et al., 2010). Conversely, permissive parenting tended to protect children in low SES families, but the trend only approached significance (Topham et al., 2010). The SESdependent relationship between permissive parenting and COWOB was supported with longitudinal data from a second study (Lane et al., 2013), where high income predicted a greater likelihood of 
permissive parenting style, and permissive parenting style predicted early and sustained childhood overweight (Lane et al., 2013). There was no difference in child BMI between authoritarian and permissive parenting styles of mothers from low SES (Lane et al., 2013; Topham et al., 2010). Other parenting styles such as authoritarian or negligent parenting were identified as risk factors for children not living in poverty (Kakinami, 2015) but these findings were not supported in a fourth study that investigated authoritative, permissive, authoritarian, rejecting and neglecting parenting styles. A positive association between rejecting parenting and child BMI was found but the relationship was not moderated by parent's education level (Rodenburg, 2011). Taken together, these findings suggest that parenting styles are an important risk factor for COWOB in higher SES families, but further research is needed to clarify the influence of the different styles.

Household-system factors. Nine studies explored the multivariate relationship between household-system factors, SES and COWOB; these included family's ethnicity/migrant-status (terms used interchangeably), single-parent households, parents' employment status and child-care attendance (Gibbs \& Forste, 2014)(see Table 4). Eight studies investigated ethnicity with six studies finding moderate-strength evidence to suggest that ethnicity was a mediator of the SES-COWOB relationship (Dubois et al., 2005; Ebenegger et al., 2011; Gibbs \& Forste, 2014; Layte et al., 2014; Strauss \& Knight, 1999; Waters et al., 2014), whereas two studies reported strong (Klebanov et al., 2014) and weak (Gopinath, 2012) evidence to reject ethnicity as a mediator. Regular child-care attendance was investigated in only one study where there was moderate strength evidence to suggest it was potential mediator of SES (Gibbs \& Forste, 2014). The impact of single-parent households and employment status were investigated in three studies (Gibbs \& Forste, 2014; Strauss \& Knight, 1999; Veldhuis et al., 2013) and one study (Veldhuis et al., 2013) respectively; all studies reported moderate strength evidence to reject a mediation effect occurring.

Ethnicity and maternal work hours were found to interact with SES. African-American and Hispanic children in low SES had lower rates of COWOB than Anglo-Saxon children (Martinson et al., 
2012) which suggests a cultural protective factor. A similar protective trend was found in UK-born children with Hispanic, Asian (Pakistani, Bangladeshi and Indian), Caribbean and African mothers, compared to Anglo-Saxon children. No cultural/ethnic patterns were reported in higher SES families (Martinson et al., 2012). In another study conducted in Hawaii; collapsed across SES, children from Samoan, Native-Hawaiian, Filipino and Hawaiian-Asian mixed were at higher risk of COWOB compared to "white" children, and children of Asian culture were at lower risk (Novotny, Oshiro, \& Wilkens, 2013). Lower SES (measured as low education level) increased the odds of COWOB in children of Samoan background but decreased the risk for other ethnic groups (Novotny et al., 2013). Ethnicity was found to interact with SES such that children in low SES families were at risk depending on their ethnic background, whereas maternal employment was found to interact with SES, such that children in high SES families were at greater risk of COWOB. For every 10 hours a mother worked (per week), children from high SES families were more likely to be overweight than children from low SES families (Anderson et al., 2003; Hawkins et al., 2008), suggesting that greater number of working hours was a risk factor for childhood overweight in high SES families only.

Social-system factors. One paper investigated the mediating effect of neighbourhood poverty on the relationship between SES (measured as household income) and COWOB, and found that after two years of age, neighbourhood poverty accounted for a significant proportion of the variation in weight trajectory between poor and non-poor families (Klebanov et al., 2014). However, because neighbourhood poverty was operationalised by the fraction of families with annual incomes under $\$ 10,000$ this mitigation would be expected.

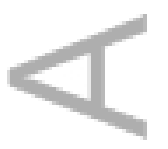

\section{Discussion}

The systematic review was driven by three research questions and each question is addressed in turn below.

This article is protected by copyright. All rights reserved. 


\section{What do studies reveal about potential mediators of the relationship between SES and COWOB?}

Although SES provides a useful way of representing the nexus of factors that often contribute to poor health and psychosocial outcomes (Adler et al., 1994), it can be tempting to reify SES which distracts attention from the mechanisms that underlie it and are of actual interest (Bradley \& Corwyn, 2002). This review identified a number of potential factors that mediate the SESCOWOB relationship. Child's birth weight and parents' weight status received the most empirical attention and support but most other factors were only tested in one or two studies which make it difficult to draw strong conclusions.

Child-system factors potentially mediating the effect of SES on COWOB were high TV time, breastfeeding (early weening), poor food intake behaviours and low birth weight. Parent-system factors were high TV time, smoking and high weight status, and the household-system factors were non-Anglo-Saxon ethnicity and less child-care attendance. These factors help explain the association between SES and COWOB and direct attention to parental behaviours. No studies explored the influence of parent attitudes, personality, knowledge, values or health behaviours as potential mediators of SES and should be studied as potentially modifiable risk and protective factors in future.

The risk factors of parental sedentary behaviour and overweight suggest children are exposed to an unhealthy home environment which sets children on a trajectory to overweight and obesity. This is consistent with Zarnowiecki et al.'s findings where parents of low SES were less likely to model health eating behaviours (2014). Moreover, the risk factor of low birth weight suggests that this unhealthy environment was in place prenatally, given evidence that low birth weight is associated with several unhealthy behaviours such as smoking and alcohol consumption (Spiegler et al., 2013). An unhealthy early childhood home environment may explain why regular child-care attendance was found to protect infants from COWOB. Pre-school aged children consume more energy dense foods 
while outside of child-care centres, than recommended (Robson, 2015), as food provisions and activities are more likely to be monitored by regulatory health bodies (Slining, 2014). Possible explanations for the mediating role of ethnicity are offered in terms of migrant status, level of education, rejection of professional qualifications (i.e., discrimination), language barriers, health literacy and access to resources (i.e., acculturative stress) (El-Sayed et al., 2011). Further investigation into the relationship between SES, ethnicity and COWOB is required. Only one study explored the mediating effects of social-system factors (Klebanov et al., 2014) but the social level factor (neighbourhood poverty) was not independent of their measure of SES (household income).

Risk factors identified at the child-, parent-, and household-system support the development of interventions that target parents/family. Such interventions could be delivered via Maternal and Child Health and Ante-natal classes to improve health knowledge and priorities. Interventions designed to work across multiple levels, such as the INFANT program (Campbell et al., 2008) have potential to be sustainable and effective (Swinburn \& Wood, 2013).

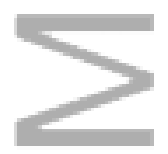

\section{What do studies reveal about the interaction influences that involve the socio-ecological} factors, SES and COWOB?

Six factors were found to interact with SES to influence COWOB. Low household income predicted weight gain in preschool girls but not boys, whereas parental education predicted weight gain in both boys and girls. The moderating effect of child sex on SES-COWOB suggests that there is something about maleness that offers some protection for boys from obesogenic influences in low SES. For example, it is possible that gender-related factors such as high activity levels of boys (Riddoch et al., 2004; Trost et al., 2002) offset some disadvantage associated with low household income for boys, but factors associated with parental education (e.g., health literacy) (Chari et al., 2014) impact boys and girls equally. It is also apparent that factors associated with culture buffer the influence of SES on COWOB. In low SES, children of African-American, Hispanic and Asian 
backgrounds were of reduced risk of COWOB compared to children of Samoan and Anglo-Saxon cultures. In poverty-stricken families children were more likely to be overweight if they were AngloSaxon than African-American or Hispanic. The mechanisms underlying these cultural influences need further exploration.

In low SES families, parental obesity (Semmler et al., 2009) and maternal depressive symptoms (Morrissey \& Dagher, 2014) were strong risk factors for COWOB, and older maternal age was a protective factor. Different factors predicted COWOB in higher SES; these were permissive parenting style (Lane et al., 2013; Topham et al., 2010), and long maternal working hours (Hawkins et al., 2008). Risk factors for middle SES families were not identified. Families of low SES are more likely to be characterised by limited resources and an abundance of chronically stressful conditions (Taylor \& Seeman, 1999). For these families, engaging in health promoting behaviours may not be a priority (due to lack of knowledge, lack of time, perceived barriers and/or perceived benefits; competing stressors) and consequently the physical and mental health status of all family members can be negatively influenced (Taylor \& Seeman, 1999). Older parents may offset this effect because they are more likely to have financial security and educational attainment (Martin, 1994), and feel more prepared to fulfil the parenting roles required (Barnes et al., 2013). In high SES, a higher level of formal education can inform more effective ways of establishing and maintaining good health. Indeed, the evidence suggests that having higher education can even off-set the well-established risk for COWOB that is associated with having obesogenic parents. However, in spite of their higher levels of education, high SES families are not immune to COWOB. The mechanisms that explain this association have yet to be explore rigorously; this is clearly an area of research that warrants more attention.

3. What are the relative strengths and limitations of studies designed to understand the effect of SES on COWOB and what recommendations can be made for future research? 
The major limitation of studies exploring mediation effects were that factors were analysed simultaneously and individual coefficients were not reported, hindering the identification of individual mediators. Furthermore, the parent subsystem was understudied, especially the psychological attributes of parents that might mediate poor health behaviours. The investigation of psychological processes such as attitudes, beliefs, self-efficacy, self-esteem, locus of control and how these interact with resources such as time, knowledge, income, etc. is an important area of investigation. How these factors differ between subgroups could provide important insight into the development of COWOB. Furthermore, the measurement of SES varied between studies and power for assessing interaction effects is often poor, there is a need for future studies to replicate findings.

There are several limitations to this review; firstly the terms 'mediator' and 'moderator' were not used in the search criteria, but in our opinion this allowed the search to be all-inclusive. Secondly, this review excluded studies that had a restricted SES sample (e.g., only low SES), where important information regarding the relationship between low SES and COWOB may have been missed. However, possible moderation effects of SES could not be tested in these studies and so they were not included. We cannot be certain that we found all the relevant studies. SES is a very common covariate of study, and there may have been studies that included a proxy measure for SES in their analyses, without reporting it in their key terms, title or abstract. Finally, this review does not include the biology of child obesity which is an important factor to understand along with the other socio-ecological factors.

In conclusion, SES cannot 'cause' OWOB in children but it can be presented as though it holds some explanatory power. We believe that SES represents a confluence of family/parentrelated factors that influence child overweight and obesity, and this review has made the first attempt to identify these from the existing literature. We hope that the findings of this review will encourage future researchers to replicate these studies in order to permit the (i) identification of candidates for intervention, and (ii) understanding of pathways through which these candidates 
affect child health outcomes. Finally, the findings of this review suggest that there are different risk factors for COWOB in different SES groups (low and high).

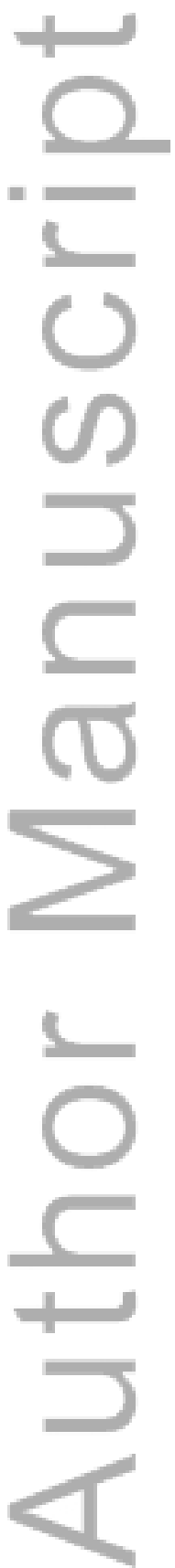

This article is protected by copyright. All rights reserved. 


\section{Key Messages:}

- The mechanisms underlying the relationship between socioeconomic status and child overweight/obesity are poorly understood.

- Potential mediators of the relationship between SES and child overweight/obesity identified at the child, parent, and household level support a multi-level approach to reducing childhood obesity.

- The investigation of psychological processes as mediators of the relationship between

= overweight/obesity and SES is under-represented in the literature.

- Intervention strategies need to take into account the potential for having different factors influence overweight/obesity at different SES levels, further research is required.

- This review recommends greater emphasis on the identification of mediators and moderators of the relationship between SES and child overweight/obesity to inform the development of interventions.

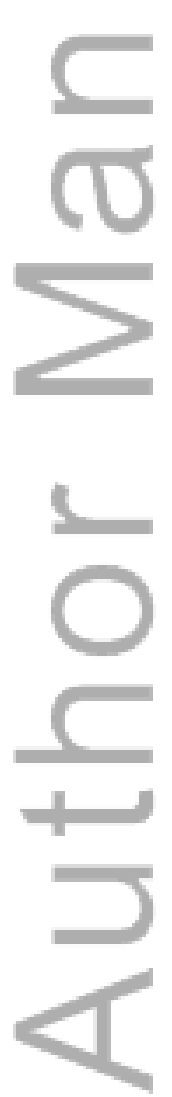

This article is protected by copyright. All rights reserved. 


\section{References}

Adler, N. E., Boyce, T., Chesney, M. A., Cohen, S., Folkman, S., Kahn, R. L., \& Syme, S. L. (1994) Socioeconomic status and health: The challenge of the gradient. Am Psychol, 49(1), 15-24. doi: 10.1037/0003-066X.49.1.15

American Psychological Association (2013) Socioeconomic status. http://www.apa.org/topics/socioeconomic-status/

Australian Bureau of Statistics (2006) Community participation of people with a disability, Australian social trends. Canberra, Australia: ABS.

Balistreri, K. S., \& Van Hook, J. (2011) Trajectories of Overweight Among US School Children: A Focus on Social and Economic Characteristics. Matern Child Health J, 15(5), 610-619. doi:

$=10.1007 / \mathrm{s} 10995-010-0622-7$

Barnes, J., Gardiner, J., Sutcliffe, A., \& Melhuish, E. (2013) The parenting of preschool children by older mothers in the United Kingdom. European Journal of Developmental Psychology, 11(4), 397-419. doi: 10.1080/17405629.2013.863728

Baron, R. M. \& Kenny, D. A. (1986) The moderator-mediator variable distinction in social psychological research: conceptual, strategic, and statistical considerations. J Personal Soc Psychol, 51 (1), 1173-1182.

Beyerlein, A., Toschke, A. M., von Kries, R. (2010). Risk factors for childhood overweight: shift of the mean body mass index and shift of the upper percentiles: results from a cross-sectional study. International Journal of Obesity, 34(4), 642-648. doi: 10.1038/ijo.2009.301

Bingham, D. D., Varela-Silva, M. I., Ferrão, M. M., Augusta, G., Mourão, M. I., Nogueira, H., Marques, V. R., Padez, C. (2013) Socio-demographic and behavioral risk factors associated with the high prevalence of overweight and obesity in Portuguese children. American Journal of Human Biology: The Official Journal Of The Human Biology Council, 25(6), 733-742. doi: 10.1002/ajhb.22440

Bleich, S. N., Segal, J., Wu, Y., Wilson, R., \& Wang, Y. (2013). Systematic Review of Community-Based Childhood Obesity Prevention Studies. Pediatrics, 132(1), e201-e210. doi: 10.1542/peds.2013-0886

Boonpleng, W., Park, C. G., Gallo, A. M., Corte, C., McCreary, L., \& Bergren, M. D. (2013) Ecological Influences of Early Childhood Obesity: A Multilevel Analysis. West J Nurs Res, 35(6), 742-759. doi: 10.1177/0193945913480275

Bradley, R. H., \& Corwyn, R. F. (2002) Socioeconomic status and child development. Annu Rev Psychol, 53, 371-399. doi: 10.1146/annurev.psych.53.100901.135233

Bronfenbrenner, U. (1979) The ecology of human development: Harvard University Press.

Brown, J. E., Broom, D. H., Nicholson, J. M., \& Bittman, M. (2010) Do working mothers raise couch potato kids? Maternal employment and children's lifestyle behaviours and weight in early

childhood. Soc Sci Med, 70(11), 1816-1824. doi: 10.1016/j.socscimed.2010.01.040

Campbell, K., Hesketh, K., Crawford, D., Salmon, J., Ball, K., \& McCallum, Z. (2008) The Infant Feeding Activity and Nutrition Trial (INFANT) an early intervention to prevent childhood obesity: Cluster-randomised controlled trial. BMC Public Health, 8(1), 103.

Campbell, K. J., \& Hesketh, K. D. (2007) Strategies which aim to positively impact on weight, physical activity, diet and sedentary behaviours in children from zero to five years. A systematic review of the literature. Obes Rev, 8(4), 327-338. doi: 10.1111/j.1467-789X.2006.00305.x

Centers for Disease Control Prevention. A SAS Program for the CDC Growth Charts. Available at www.cdc.giv/nccdphp/dnpao/growthcharts/resources/sas.htm/.

Chari, R., Warsh, J., Ketterer, T., Hossain, J., \& Sharif, I. (2014) Association between health literacy and child and adolescent obesity. Patient Educ Couns, 94(1), 61-66. doi:

10.1016/j.pec.2013.09.006 
Cho, Y.-G., Kang, J.-H., Kim, K.-A., \& Song, J.-H. (2009). The relationship between low maternal education level and children's overweight in the Korean society. Obes Res Clin Pract, 3(3), 133-140. doi: 10.1016/j.orcp.2009.03.002

Cockrell Skinner, A., \& Foster, E. M. (2013) Systems science and childhood obesity: a systematic review and new directions. J Obes Overweight, 2013, 129193-129193. doi: $10.1155 / 2013 / 129193$

Cohen, A. K., Rai, M., Rehkopf, D. H., \& Abrams, B. (2013) Educational attainment and obesity: a systematic review. Obes Rev, 14(12), 989-1005. doi: 10.1111/obr.12062

Cole, T.J., Bellizzi, M. C., Flegal, K. M., \& Dietz, W. H. (2000) Establishing a standard definition for child overweight and obesity worldwide: international survey. BMJ, 320(7244), 1240-1243.

Davison, K. K., \& Birch, L. L. (2001) Childhood overweight: a contextual model and recommendations for future research. Obes Rev, 2(3), 159-171.

Davison, K. K., Jurkowski, J. M., \& Lawson, H. A. (2012) Reframing family-centred obesity prevention using the Family Ecological Model. Public Health Nutr, 16(10), 1861-1869. doi: 10.1017/S1368980012004533

Demment, M. M. H., Jere D.; Olson, Christine M. (2014) Changes in family income status and the development of overweight and obesity from 2 to 15 years: a longitudinal study. BMC Public Health, 14(1), 1-20. doi: 10.1186/1471-2458-14-417

Dubois, L., Girard, M., \& Kent, M. P. (2006) Breakfast eating and overweight in a pre-school population: is there a link? Public Health Nutr, 9(4), 436-442.

Dubois, L. \& Girard, M. (2006) Early determinants of overweight at 4.5 years in a population-based longitudinal study. International Journal of Obesity, 30(4), 610-617. doi: 10.1038/sj.ijo.0803141

Ebenegger, V., Marques-Vidal, P. M., Nydegger, A., Laimbacher, J., Niederer, I., Bürgi, F. \& Puder, J. J. (2011) Independent contribution of parental migrant status and educational level to adiposity and eating habits in preschool children. Eur J Clin Nutr, 65(2), 210-218. doi: 10.1038/ejcn.2010.248

El-Sayed, A. M., Scarborough, P., \& Galea, S. (2011) Ethnic inequalities in obesity among children and adults in the UK: a systematic review of the literature. Obesity Reviews, 12(5), e516-e534. doi: 10.1111/j.1467-789X.2010.00829.x

Gibbs, B., \& Forste, R. (2014) Socioeconomic status, infant feeding practices and early childhood obesity. Pediatr Obes, 9, 135-146.

Gopinath, B. Baur, L. A., Burlutsky, G., Robaei, D., \& Mitchell, P. (2012) Socio-economic, familial and perinatal factors associated with obesity in Sydney schoolchildren. Journal Of Paediatrics And Child Health, 48(1), 44-51.

Guo, S. S., Wu, W., Chumlea, W. C., \& Roche, A. F. (2002) Predicting overweight and obesity in adulthood from body mass index values in childhood and adolescence. Am J Clin Nutr, 76(3), 653-658.

Hancock, K. J., Lawrence, D., Zubrick, S. R. (2014) Higher maternal protectiveness is associated with higher odds of child overweight and obesity: a longitudinal Australian study. PLoS ONE, 9(6), e100686-e100686. doi: 10.1371/journal.pone.0100686

Hawkins, S. S., Cole, T. J., Law, C., \& Millennium Cohort Study Child, H. (2008) Maternal employment and early childhood overweight: findings from the UK Millennium Cohort Study. Int J Pediatr Obes, 32(1), 30-38. doi: 10.1038/sj.ijo.0803682

International Monetary Fund. (2013) from http://www.imf.org/external/index.htm

Jansen, P. W., Mensah, F. K., Nicholson, J. M., \& Wake, M. (2013) Family and Neighbourhood Socioeconomic Inequalities in Childhood Trajectories of BMI and Overweight: Longitudinal Study of Australian Children. PLOS ONE, 8(7).

Kakinami, L. B., Tracie A.; Séguin, Louise; Paradis, Gilles. (2015) Parenting style and obesity risk in children. Preventive Medicine: An International Journal Devoted to Practice and Theory, 75, 18-22. doi: 10.1016/j.ypmed.2015.03.005

This article is protected by copyright. All rights reserved. 
Klebanov, P. K., Evans, G. W., \& Brooks-Gunn, J. (2014) Poverty, ethnicity, and risk of obesity among low birth weight infants. J Appl Dev Psychol, 35(3), 245-253. doi: 10.1016/j.appdev.2014.01.003

Lane, S. P., Bluestone, C., \& Burke, C. T. (2013) Trajectories of BMI from early childhood through early adolescence: SES and psychosocial predictors. Br J Health Psychol, 18, 66-82. doi: 10.1111/j.2044-8287.2012.02078.x

Layte, R., Bennett, A., McCrory, C., \& Kearney, J. (2014) Social class variation in the predictors of rapid growth in infancy and obesity at age 3 years. Int J Obes, 38(1), 82-90. doi: 10.1038/ijo.2013.160

MacKinnon, D. P., Fairchild, A. J. \& Fritz, M. S. (2007) Mediation analysis. Ann Rev Psychol. 58, 593615. doi: $10.1146 /$ annurev.psych.58.110405.085542.

Martin, S. (1994) Women's education and family timing: outcomes and trends associated with age at marriage and first birth. In K. Neckerman (Ed.), Social inequality. (pp. 79-118). New York: Russel Sage Foundation.

Martinson, M. L., McLanahan, S., \& Brooks-Gunn, J. (2012) Race/Ethnic and Nativity Disparities in Child Overweight in the United States and England. Ann Am Acad Pol Soc Sci, 643, 219-238. doi: $10.1177 / 0002716212445750$

Moher, D., Liberati, A., Tetzlaff, J., \& Altman, D. (2009) Preferred Reporting Items for Systematic Reviews and Meta-Analyses: The PRISMA Statement. PLoS Med, 6(6), e1000097.

Moraeus, L., Lissner, L., Yngve, A., Poortvliet, E., Al-Ansari, U, \& Sjöberg, A. (2012) Multi-level influences on childhood obesity in Sweden: Societal factors, parental determinants and child's lifestyle. International Journal of Obesity, 36(7), 969-976. doi: 10.1038/ijo.2012.79

Morrissey, T. W., \& Dagher, R. K. (2014) A longitudinal analysis of maternal depressive symptoms and children's food consumption and weight outcomes. Public Health Nutr, 1-10.

Nielsen, L. (2011) Classification of countries based on their level of development: How it is done and how it could be done. In C. Pattillo (Ed.): International Monetary Fund.

Novotny, R., Oshiro, C. E. S., \& Wilkens, L. R. (2013) Prevalence of Childhood Obesity among Young Multiethnic Children from a Health Maintenance Organization in Hawaii. Child Obes, 9(1), 35-42. doi: 10.1089/chi.2012.0103

Riddoch, C. J., Andersen, L. B., Wedderkopp, N., Harro, M., Klasson-Heggebo, L., Sardinha, L. B., \& Ekelund, U. (2004) Physical activity levels and patterns of 9-and 15-yr-old European children. Med Sci Sports Exerc, 36(1), 86-92.

Robson, S. M., Khoury, J. C., Kalkwarf, H. J., \& Copeland, K. (2015) Dietary Intake of Children Attending Full-Time Child Care: What Are They Eating Away from the Child-Care Center? Journal of the Academy of Nutrition \& Dietetics, 115(9), 1472-1478. doi: 10.1016/j.jand.2015.02.029

Rodenburg, G., Kremers, S. P. J., Oenema, A., van de Mheen, D. (2011) Psychological control by parents is associated with a higher child weight. International Journal of Pediatric Obesity, 6(5/6), 442-449. doi: 10.3109/17477166.2011.590203

Semmler, C., Ashcroft, J., van Jaarsveld, C. H. M., Carnell, S., \& Wardle, J. (2009) Development of Overweight in Children in Relation to Parental Weight and Socioeconomic Status. Obesity, 17(4), 814-820. doi: 10.1038/oby.2008.621

Shrewsbury, V., \& Wardle, J. (2008) Socioeconomic Status and Adiposity in Childhood: A Systematic Review of Cross-sectional Studies 1990-2005. Obesity, 16(2), 275-284. doi: 10.1038/oby.2007.35

Slining, M. M., Neelon, S. E. B., Duffey, K. J. (2014) A review of state regulations to promote infant physical activity in child care. International Journal of Behavioral Nutrition and Physical Activity, 11(139). doi: 10.1186/s12966-014-0139-3

Sobal, J., \& Stunkard, A. J. (1989) Socioeconomic status and obesity: A review of the literature. Psychol Bull, 105(2), 260-275. doi: 10.1037/0033-2909.105.2.260

This article is protected by copyright. All rights reserved. 
Spiegler, J., Jensen, R., Segerer, H., Ehlers, S., Kühn, T., Jenke, A., Gebauer C., Möller, J., Orlikowsky, T, Heitmann, F., Boeckenholt, K., Herting, E., Göpel, W. (2013) Influence of smoking and alcohol during pregnancy on outcome of VLBW infants. Zeitschrift fur Geburtshilfe und Neonatologie, 217(6), 215-219.

Strauss, R. S., \& Knight, J. (1999) Influence of the home environment on the development of obesity in children. Pediatrics, 103(6). doi: 10.1542/peds.103.6.e85

Swinburn, B., \& Wood, A. (2013) Progress on obesity prevention over 20 years in Australia and New Zealand. Obes Rev, 14, 60-68. doi: 10.1111/obr.12103

Taylor, S. E., \& Seeman, T. E. (1999) Psychosocial Resources and the SES-Health Relationship. Ann N Y Acad Sci, 896(1), 210-225. doi: 10.1111/j.1749-6632.1999.tb08117.x

Topham, G. L., Page, M. C., Hubbs-Tait, L., Rutledge, J. M., Kennedy, T. S., Shriver, L., \& Harrist, A. W. = (2010) Maternal depression and socio-economic status moderate the parenting style/child obesity association. Public Health Nutr, 13(8), 1237-1244. doi: 10.1017/S1368980009992163

Trost, S. G., Pate, R. R., Sallis, J. F., Freedson, P. S., Taylor, W. C., Dowda, M., \& Sirard, J. (2002) Age and gender differences in objectively measured physical activity in youth. Med Sci Sports Exerc, 34(2), 350-355.

Veldhuis, L., Vogel, I., van Rossem, L., Renders, C. M., HiraSing, R. A., Mackenbach, J. P., \& Raat, H. (2013) Influence of maternal and child lifestyle-related characteristics on the socioeconomic inequality in overweight and obesity among 5-year-old children; the "Be active, eat right" study. Int J Environ Res Public Health, 10(6), 2236-2247.

Waters, E., Silva-Sanigorski, A. D., Burford, B. J., Brown, T., Campbell, K. J., Gao, Y., Armstrong, R., Prosser, L., \& Summerbell, C. D. (2014) Interventions for preventing obesity in children. Sao Paulo Medical Journal, 132(2), 128-129.

Wehrly, S. E., Bonilla, C., Perez, M., \& Liew, J. (2014) Controlling parental feeding practices and child body composition in ethnically and economically diverse preschool children. Appetite, 73, 163-171. doi: 10.1016/j.appet.2013.11.009

Whitaker, R. C., Wright, J. A., Pepe, M. S., Seidel, K. D., \& Dietz, W. H. (1997) Predicting obesity in young adulthood from childhood and parental obesity. N Engl J Med, 337(13), 869-873. doi: 10.1056/nejm199709253371301

World Health Organization. (2013) Childhood overweight and obesity. from http://www.who.int/dietphysicalactivity/childhood/en/

Zarnowiecki, D. M., Dollman, J., \& Parletta, N. (2014) Associations between predictors of children's dietary intake and socioeconomic position: a systematic review of the literature. Obesity Reviews, 15(5), 375-391. doi: 10.1111/obr.12139

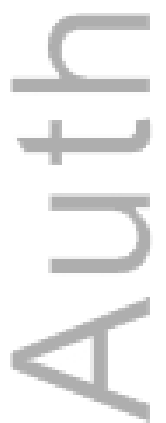

This article is protected by copyright. All rights reserved. 
Table 1. Search terms and subject heading terms

\begin{tabular}{|c|c|c|c|}
\hline & OR & $\begin{array}{l}\text { AND } \\
\text { OR }\end{array}$ & $\begin{array}{l}\text { AND } \\
\text { OR }\end{array}$ \\
\hline 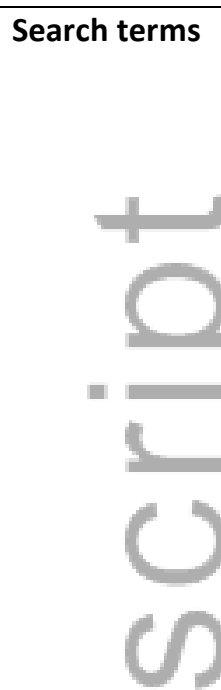 & $\begin{array}{l}\text { "environment* factors" } \\
\text { SES } \\
\text { disadvantag* } \\
\text { socio*economic } \\
\text { background } \\
\text { rich* } \\
\text { poor* } \\
\text { neighbo* } \\
\text { education } \\
\text { income } \\
\text { occupation* }\end{array}$ & $\begin{array}{l}\text { psychosocial } \\
\text { "parent* attitude" } \\
\text { "parent* knowledge" } \\
\text { "parent* beliefs" } \\
\text { "parent* practice" } \\
\text { maternal } \\
\text { paternal } \\
\text { caregiver }\end{array}$ & $\begin{array}{l}\text { "child* obesity" } \\
\text { "child* over weight" } \\
\text { "weight gain" } \\
\text { "fat child*" } \\
\text { "child BMI" } \\
\text { "child Body Mass Index" }\end{array}$ \\
\hline \multicolumn{4}{|c|}{ Subject heading terms } \\
\hline Psycinfo & "Socioeconomic Status" & $\begin{array}{l}\text { "Parental Attitudes" } \\
\text { "Parental } \\
\text { Characteristics" } \\
\text { "Parenting" }\end{array}$ & N/A \\
\hline Medline & N/A & "Parenting" & "Pediatric obesity" \\
\hline CINAHL & "Socioeconomic Factors" & $\begin{array}{l}\text { "Parenting" } \\
\text { "Parental Attitudes" } \\
\text { "Parental Behavior" } \\
\text { "Parent-Child Relations" }\end{array}$ & "Pediatric obesity" \\
\hline $\begin{array}{l}\text { Academic } \\
\text { Search } \\
\text { Complete }\end{array}$ & $\begin{array}{l}\text { "SOCIOECONOMIC } \\
\text { factors" }\end{array}$ & $\begin{array}{l}\text { "PARENTING" } \\
\text { "PARENTING -- Cross- } \\
\text { cultural studies" } \\
\text { "PARENTING -- } \\
\text { Psychological aspects" } \\
\text { "PARENTAL influences" }\end{array}$ & N/A \\
\hline Scopus & $\mathrm{N} / \mathrm{A}$ & N/A & $\mathrm{N} / \mathrm{A}$ \\
\hline $\begin{array}{l}\text { Web of } \\
\text { Knowledge }\end{array}$ & N/A & N/A & N/A \\
\hline
\end{tabular}




\begin{tabular}{|c|c|c|c|c|c|}
\hline \multicolumn{6}{|c|}{ Twenty studies investigating potential mediation effects } \\
\hline $\begin{array}{l}\text { a. First author (date } \\
\text { of publication) } \\
\text { b. Country } \\
\text { c. Quality score }\end{array}$ & Main study aim & $\begin{array}{l}\text { d. Sample size } \\
\text { e. Sample mean age } \\
\text { f. Sample demographics } \\
\text { g. Study design } \\
\text { h. Statistical Analysis } \\
\end{array}$ & $\begin{array}{l}\text { COWOB } \\
\text { class. } \\
\text { system }\end{array}$ & $\begin{array}{l}\text { Socioeconomic status } \\
\text { proxy }\end{array}$ & Variables \\
\hline $\begin{array}{l}\text { a. Balistreri (2011) } \\
\text { b. USA } \\
\text { c. } 7.5\end{array}$ & $\begin{array}{l}\text { To identify trajectories } \\
\text { of childhood } \\
\text { overweight, and to } \\
\text { measure the } \\
\text { association between } \\
\text { social/economic } \\
\text { factors with trajectory } \\
\text { membership. }\end{array}$ & $\begin{array}{l}\text { d. 13,970 } \\
\text { e. T1: Kindergarten T2: First grade T3: } \\
\text { Third grade T4: Fifth grade and T5: } \\
\text { Eigth grade } \\
\text { f. Early Childhood Longitudinal Study- } \\
\text { Kindergarten Cohort (ECLS-K). } 25 \% \\
\text { come from an immigrant family. } 89 \% \text { of } \\
\text { children had one parent with at least } \\
\text { high school degree. } \\
\text { g. Longitudinal } \\
\text { h. Mixture Models identified } 3 \\
\text { trajectories: 'Normal weight', 'Gradual } \\
\text { onset', 'Always' overweight' } \\
\text { Multinomial logistic regression }\end{array}$ & CDC & $\begin{array}{l}\text { Parental education } \\
\text { No high school, high } \\
\text { school degree, some } \\
\text { college or college } \\
\text { Annual household } \\
\text { income at T1 }\end{array}$ & - Child's birth weight \\
\hline $\begin{array}{l}\text { a. Beyerlein (2010) } \\
\text { b. Germany } \\
\text { c. } 7.5\end{array}$ & $\begin{array}{l}\text { To assess the possible } \\
\text { differences in } \\
\text { associations of several } \\
\text { risk factors by } \\
\text { subgroups of children's } \\
\text { BMI distribution. }\end{array}$ & $\begin{array}{l}\text { d. } 9698 \\
\text { e. 5-6 years } \\
\text { f. School-entry health examination in } \\
\text { Bavaria, Southern Germany 1999-2002. } \\
27.9 \% \text { of parents had elementary or } \\
\text { less education. } \\
\text { g. Cross-sectional } \\
\text { h. Quantile regression }\end{array}$ & WHO & $\begin{array}{l}\text { Parental education } \\
\text { Low education } \\
\text { (neither mother nor } \\
\text { father achieved O- } \\
\text { level/GCSE) }\end{array}$ & $\begin{array}{l}\text { - Child's birth weight } \\
\text { - High television viewing: >2h day } \\
\text { - Breastfeeding: Ever breastfeed? Yes vs. No } \\
\text { - Mother smoking during pregnancy }\end{array}$ \\
\hline $\begin{array}{l}\text { a. Bingham (2013) } \\
\text { b. Portugal } \\
\text { c. } 7\end{array}$ & $\begin{array}{l}\text { To update the } \\
\text { prevalence of } \\
\text { overweight and obesity } \\
\text { in Portuguese children } \\
\text { and to explore the } \\
\text { influence and risks of } \\
\text { socio-demographic } \\
\text { factors and } \\
\text { behavioural factors. }\end{array}$ & $\begin{array}{l}\text { d. } 17,136 \\
\text { e. } 3-10 \text { years } \\
\text { f. Portuguese nationally representative } \\
\text { sample } \\
\text { g. Cross-sectional } \\
\text { h. Logistic regression }\end{array}$ & IOTF & $\begin{array}{l}\text { Parental education } \\
\text { Primary (4 years), 6, 9, } \\
12 \text { years, University } \\
\text { (>12 years) }\end{array}$ & - Parent BMI \\
\hline a. First author (date & Main study aim & d. Sample size & COWOB & Socioeconomic status & Variables \\
\hline
\end{tabular}

This article is protected by copyright. All rights reserved. 


\begin{tabular}{|c|c|c|c|c|c|}
\hline $\begin{array}{l}\text { of publication) } \\
\text { b. Country } \\
\text { c. Quality score }\end{array}$ & & $\begin{array}{l}\text { e. Sample mean age } \\
\text { f. Sample demographics } \\
\text { g. Study design } \\
\text { h. Statistical Analysis }\end{array}$ & $\begin{array}{l}\text { Class. } \\
\text { system }\end{array}$ & proxy & \\
\hline $\begin{array}{l}\text { a. Cho (2009) } \\
\text { b. Korea } \\
\text { c. } 6\end{array}$ & $\begin{array}{l}\text { To investigate the } \\
\text { relationship between } \\
\text { socio economic status } \\
\text { and childhood } \\
\text { adiposity in Korea. }\end{array}$ & $\begin{array}{l}\text { d. } 429 \\
\text { e. } 7.9 \text { years } \\
\text { f. Well-educated, middle class: } 80 \% \text { of } \\
\text { mothers and } 87.4 \% \text { of fathers } \\
\text { graduated from university } \\
\text { g. Cross-sectional } \\
\text { h. Logistic regression }\end{array}$ & $\begin{array}{l}\text { 1998 } \\
\text { Growth } \\
\text { Chart for } \\
\text { Korean } \\
\text { Children } \\
\text { (2-18 } \\
\text { years) }\end{array}$ & $\begin{array}{l}\text { Parental education } \\
\text { Low }=\leq \text { high school } \\
\text { High }=\geq \text { college } \\
\text { Total household } \\
\text { income } \\
\text { Low }=<4 \text { million won } \\
\text { High }=\geq 4 \text { million won }\end{array}$ & $\begin{array}{l}\text { - Child sex } \\
\text { - Child age } \\
\text { - Child's birth weight } \\
\text { - Screen time: time watching TV or using } \\
\text { computer (games or internet). }<90 \text { min/day vs. } \\
\geq 90 \text { min/day. Excluding time in school } \\
\text { activities } \\
\text { - Eating fresh vegetables: } \leq 6 \text { times/week vs. } \\
\text { daily) } \\
\text { - Fruit: } \leq 6 \text { times/week vs. daily } \\
\text { - Fast-food: }<1 \text { time/week vs. } \geq 1 \text { time/week } \\
\text { - Moderate physical activity: } \leq 2 \text { time/week vs. } \geq \\
3 \text { time/week } \\
\text { - Parent BMI }\end{array}$ \\
\hline $\begin{array}{l}\text { a. Demment (2014) } \\
\text { b. USA } \\
\text { c. } 5.5\end{array}$ & $\begin{array}{l}\text { To examine the } \\
\text { associations between } \\
\text { changes in family } \\
\text { income status, early- } \\
\text { life risk factors, and } \\
\text { body mass index (BMI) } \\
\text { z-score trajectory from } \\
\text { age } 2 \text { to } 15 \text { years. }\end{array}$ & $\begin{array}{l}\text { d. } 595 \\
\text { e. 2-15 years } \\
\text { f. Bassett Mothers Health Project } \\
\text { g. Longitudinal } \\
\text { h. Logistic regression }\end{array}$ & WHO & $\begin{array}{l}\text { Household income } \\
\text { trajectory } \\
\text { Movement in and out } \\
\text { of low-income }\end{array}$ & $\begin{array}{l}\text { - Child's birth weight } \\
\text { - Maternal overweight/obesity }\end{array}$ \\
\hline $\begin{array}{l}\text { a. Dubois ( } 200 \\
\text { b. Canada } \\
\text { c. } 7.5\end{array}$ & $\begin{array}{l}\text { To analyse the socio- } \\
\text { economic factors } \\
\text { related to breakfast } \\
\text { eating, and the } \\
\text { association between } \\
\text { breakfast eating and } \\
\text { childhood overweight. }\end{array}$ & $\begin{array}{l}\text { d. } 1549 \\
\text { e. } 4.5 \text { years } \\
\text { f. Quebec Longitudinal Study of Child } \\
\text { Development. Nationally } \\
\text { representative sample. } \\
\text { g. Cross-sectional } \\
\text { h. Logistic regression }\end{array}$ & $\begin{array}{l}\text { CDC } \\
\text { IOTF }\end{array}$ & $\begin{array}{l}\text { Mother's education } \\
\text { No high school } \\
\text { High school } \\
\text { Diploma } \\
\text { College education } \\
\text { Household annual } \\
\text { income } \\
<\$ 20000 \text { vs. } \$ 20000- \\
\$ 39999 \text { vs. } \$ 40000- \\
\$ 59999 \text { vs. } \geq \$ 60000\end{array}$ & $\begin{array}{l}\text { - Child sex } \\
\text { - Breakfast eating: eating breakfast everyday vs. } \\
\text { not everyday } \\
\text { - Smoked during pregnancy } \\
\text { - Number of overweight/obese parents } \\
\text { - Ethnicity: non-immigrant / immigrant }\end{array}$ \\
\hline $\begin{array}{l}\text { a. First author (date } \\
\text { of publication) } \\
\text { b. Country }\end{array}$ & Main study aim & $\begin{array}{l}\text { d. Sample size } \\
\text { e. Sample mean age } \\
\text { f. Sample demographics }\end{array}$ & $\begin{array}{l}\text { COWOB } \\
\text { Class. } \\
\text { system }\end{array}$ & $\begin{array}{l}\text { Socioeconomic status } \\
\text { proxy }\end{array}$ & Variables \\
\hline
\end{tabular}

This article is protected by copyright. All rights reserved. 


\begin{tabular}{|c|c|c|c|c|c|}
\hline c. Quality score & & $\begin{array}{l}\text { g. Study design } \\
\text { h. Statistical Analysis }\end{array}$ & & & \\
\hline $\begin{array}{l}\text { a. Dubois (2006) } \\
\text { b. Canada } \\
\text { c. } 6.5\end{array}$ & $\begin{array}{l}\text { To examine a broad } \\
\text { range of factors that } \\
\text { may simultaneously } \\
\text { contribute to } \\
\text { childhood overweight } \\
\text { in a population-based } \\
\text { cohort of children } \\
\text { followed from birth to } \\
4.5 \text { years, to determine } \\
\text { which factors exert the } \\
\text { most influence in early } \\
\text { life. }\end{array}$ & $\begin{array}{l}\text { d. } 1450 \\
\text { e. } 4-5 \text { years } \\
\text { f. Quebec Longitudinal Study of Child } \\
\quad \text { Development (QLSCD) } \\
\text { g. Longitudinal } \\
\text { h. Logistic regression }\end{array}$ & CDC & $\begin{array}{l}\text { Household income } \\
\text { Less than } \$ 20000 \text {, } \\
\$ 20-\$ 39999, \$ 40- \\
\$ 59999, \$ 60000+\end{array}$ & - Parent BMI \\
\hline $\begin{array}{l}\text { a. Ebenegger (2011) } \\
\text { b. Switzerland } \\
\text { c. } 5.5\end{array}$ & $\begin{array}{l}\text { To assess the } \\
\text { independent } \\
\text { contributions of } \\
\text { parental migrant status } \\
\text { and educational level } \\
\text { on childhood adiposity } \\
\text { and eating habits. }\end{array}$ & $\begin{array}{l}\text { d. } 542 \\
\text { e. } 5.2 \text { years } \\
\text { f. } 71 \% \text { had a migrant parent, } 37 \% \text { had at } \\
\text { least one parent of low education level. } \\
\text { g. Cross-sectional } \\
\text { h. Mixed linear regression and logistic } \\
\text { regression }\end{array}$ & $\begin{array}{l}\text { Swiss } \\
\text { National } \\
\text { Percentil } \\
\text { es, } 1989\end{array}$ & $\begin{array}{l}\text { Parental education } \\
\text { Low }=\leq 9 \text { years of } \\
\text { formal education } \\
\text { High }=>10 \text { years of } \\
\text { formal education }\end{array}$ & $\begin{array}{l}\text { - Eating habits: daily frequency of consumption } \\
\text { of water, caloric beverages, fruit, vegetables, } \\
\text { fatty foods, sweet foods, omission of breakfast, } \\
\text { meals in front of television, snacks in front of } \\
\text { the television } \\
\text { - Parent migrant status: place of birth }\end{array}$ \\
\hline $\begin{array}{l}\text { a. Gibbs (2014) } \\
\text { b. USA } \\
\text { c. } 7.5\end{array}$ & $\begin{array}{l}\text { To examine the impact } \\
\text { of infant feeding } \\
\text { practices in child } \\
\text { obesity and identify } \\
\text { the mechanisms that } \\
\text { link SES with child } \\
\text { obesity }\end{array}$ & $\begin{array}{l}\text { d. } 8030 \\
\text { e. } 9 \text { months to } 2 \text { years } \\
\text { f. Early Childhood Longitudinal Study } \\
\text { (ECLS-B) } \\
\text { g. Longitudinal } \\
\text { h. Logistic regression }\end{array}$ & $\begin{array}{l}\text { IOTF } \\
\text { CDC } \\
\text { WHO }\end{array}$ & $\begin{array}{l}\text { Composite score } \\
\text { Family SES was } \\
\text { measured by a } \\
\text { composite scale } \\
\text { consisting of } \\
\text { household income, } \\
\text { parental education } \\
\text { and occupational } \\
\text { prestige created by } \\
\text { the National } \\
\text { Center for Educational } \\
\text { Statistics. }\end{array}$ & $\begin{array}{l}\text { - Child sex } \\
\text { - Child's birth weight } \\
\text { - Unhealthy infant feeding practices: } \\
\text { predominant breastfeeding, predominant } \\
\text { formula feeding, and fed both breast milk and } \\
\text { formula in first } 6 \text { months } \\
\text { - Maternal BMI: Self report height and weight } \\
\text { - Mother's age at child's birth } \\
\text { - Current smoking; Yes or No } \\
\text { - Maternal depression: Abbreviated form of the } \\
\text { Center for Epidemiologic Studies Depression } \\
\text { Scale } \\
\text { - Day care attendance: Regular attendance, Yes } \\
\text { or No } \\
\text { - Ethnicity: White, black, Hispanic, other. }\end{array}$ \\
\hline $\begin{array}{l}\text { a. First author (date } \\
\text { of publication) } \\
\text { b. Country } \\
\text { c. Quality score }\end{array}$ & Main study aim & $\begin{array}{l}\text { d. Sample size } \\
\text { e. Sample mean age } \\
\text { f. Sample demographics } \\
\text { g. Study design }\end{array}$ & $\begin{array}{l}\text { COWOB } \\
\text { class. } \\
\text { system }\end{array}$ & $\begin{array}{l}\text { Socioeconomic status } \\
\text { proxy }\end{array}$ & Variables \\
\hline
\end{tabular}

This article is protected by copyright. All rights reserved. 


\begin{tabular}{|c|c|c|c|c|c|}
\hline 1 & & h. Statistical Analysis & & & \\
\hline $\begin{array}{l}\text { a. Gopinath (2012) } \\
\text { b. Australia } \\
\text { c. } 7.5\end{array}$ & $\begin{array}{l}\text { To examine } \\
\text { associations between } \\
\text { socio-economic, } \\
\text { familial and perinatal } \\
\text { factors with } \\
\text { overweight/obesity in } \\
6 \text { - and 12-year-old } \\
\text { schoolchildren. }\end{array}$ & $\begin{array}{l}\text { d. } 4094 \\
\text { e. } 6 \text { years (results from } 12 \text { year olds not } \\
\text { reviewed) } \\
\text { f. Sydney Childhood Eye Study } \\
\text { g. Cross-sectional } \\
\text { h. Logistic regression }\end{array}$ & IOTF & $\begin{array}{l}\text { Parent education } \\
\text { University or less than } \\
\text { university }\end{array}$ & $\begin{array}{l}\text { - Child's birth weight: low: } \leq 2499 \mathrm{~g} \text {, normal: } \\
\text { 2500-4000g, high: } \geq 4001 \mathrm{~g} \\
\text { - Smoking during pregnancy } \\
\text { - Ethnicity: White, East Asian, South Asian, } \\
\text { Middle Eastern or Others/Mixed }\end{array}$ \\
\hline $\begin{array}{l}\text { a. Hancock (2014) } \\
\text { b. Australia } \\
\text { c. } 7\end{array}$ & $\begin{array}{l}\text { To examine the } \\
\text { longitudinal } \\
\text { relationships between } \\
\text { maternal } \\
\text { protectiveness and } \\
\text { child overweight and } \\
\text { obesity. }\end{array}$ & $\begin{array}{l}\text { d. } 2596 \\
\text { e. } 4-5 \text { years } \\
\text { f. Longitudinal Study of Australian } \\
\quad \text { Children (LSAC), nationally } \\
\quad \text { representative sample } \\
\text { g. Longitudinal } \\
\text { h. Regression }\end{array}$ & IOTF & $\begin{array}{l}\text { Household income } \\
<\$ 599, \$ 600-\$ 999 \text { per } \\
\text { week, } \$ 1000-\$ 1999 \\
\text { per week, and }>\$ 2000 \\
\text { per week. }\end{array}$ & - Parent BMI \\
\hline $\begin{array}{l}\text { a. Jansen (2013) } \\
\text { b. Australia } \\
\text { c. } 7\end{array}$ & $\begin{array}{l}\text { To determine the } \\
\text { timing and strength of } \\
\text { the association } \\
\text { between SES and } \\
\text { children's BMI in the } \\
\text { pre- and primary } \\
\text { school years, and to } \\
\text { examine SES } \\
\text { differences in } \\
\text { overweight trajectories } \\
\text { across childhood }\end{array}$ & $\begin{array}{l}\text { d. } 4949 \\
\text { e. T1: 4-5 years, T2: 10-11 years } \\
\text { f. Longitudinal Study of Australian } \\
\text { Children (LSAC), nationally } \\
\text { representative sample } \\
\text { g. Longitudinal } \\
\text { h. Latent class analysis identified three } \\
\text { main trajectories: stable-normal, late- } \\
\text { onset overweight, persistent } \\
\text { overweight/obese, resolving } \\
\text { overweight. } \\
\text { Multinomial logistic regression }\end{array}$ & IOTF & $\begin{array}{l}\text { Composite score } \\
\text { Equivalised annual } \\
\text { family income, years } \\
\text { and education and } \\
\text { current or most } \\
\text { recent occupational } \\
\text { status. }\end{array}$ & $\begin{array}{l}\text { - Child's birth weight } \\
\text { - Parental BMI: Self-reported non-overweight, } \\
\text { overweight, obese }\end{array}$ \\
\hline $\begin{array}{l}\text { a. Klebanov (2014) } \\
\text { b. USA } \\
\text { c. } 5.5\end{array}$ & $\begin{array}{l}\text { To examine the BMI } \\
\text { trajectories of children } \\
\text { in early childhood, as a } \\
\text { function of ethnicity } \\
\text { and poverty }\end{array}$ & $\begin{array}{l}\text { d. } 985 \\
\text { e. T1: } 2 \text { years, T2: } 6.5 \text { years } \\
\text { f. Infant Health and Development } \\
\text { program - oversample of African- } \\
\text { American and families at or below the } \\
\text { poverty threshold } \\
\text { g. Longitudinal } \\
\text { h. Multilevel modelling }\end{array}$ & $\begin{array}{l}\text { BMI only, } \\
\text { no } \\
\text { classifica } \\
\text { tion } \\
\text { system } \\
\text { reported }\end{array}$ & $\begin{array}{l}\text { Adjusted annual } \\
\text { household income } \\
\text { Poverty }=<\text { families of } \\
\text { three }(\$ 8700 \text { USD), } \\
\text { four }(\$ 11,200) \text { and } \\
\text { five }(\$ 13,300) \text { person- } \\
\text { families }\end{array}$ & $\begin{array}{l}\text { - Child's birth weight } \\
\text { - Ethnicity: African-American, Hispanic- } \\
\text { American, Anglo-American } \\
\text { Neighbourhood poverty: the fraction of families } \\
\text { with annual incomes under } \$ 10,000\end{array}$ \\
\hline $\begin{array}{l}\text { a. First author (date } \\
\text { of publication) } \\
\text { b. Country } \\
\text { c. Quality score }\end{array}$ & Main study aim & $\begin{array}{l}\text { d. Sample size } \\
\text { e. Sample mean age } \\
\text { f. Sample demographics } \\
\text { g. Study design } \\
\text { h. Statistical Analysis } \\
\end{array}$ & $\begin{array}{l}\text { COWOB } \\
\text { class. } \\
\text { system }\end{array}$ & $\begin{array}{l}\text { Socioeconomic status } \\
\text { proxy }\end{array}$ & Variables \\
\hline
\end{tabular}

This article is protected by copyright. All rights reserved. 


\begin{tabular}{|c|c|c|c|c|c|}
\hline $\begin{array}{l}\text { a. Layte (2014) } \\
\text { b. Ireland } \\
\text { c. } 7.5\end{array}$ & $\begin{array}{l}\text { To examine the extent } \\
\text { to which child and } \\
\text { lifestyle factors explain } \\
\text { social class inequalities } \\
\text { in the risk of obesity at } \\
\text { three years }\end{array}$ & $\begin{array}{l}\text { d. } 11,134 \\
\text { e. T2: } 3 \text { years } \\
\text { f. Nationally representative sample of } \\
\text { Irish children and their families } \\
\text { g. Longitudinal \& Cross-sectional } \\
\text { h. Logistic regression }\end{array}$ & IOTF & $\begin{array}{l}\text { Household social class } \\
\text { Number of parents } \\
\text { actively employed }\end{array}$ & $\begin{array}{l}\text { - Child's birth weight } \\
\text { - Child dietary quality: low, medium and high } \\
\text { - Daily TV time: <hour daily, <2h daily, } 2+\text { hours } \\
\text { daily } \\
\text { - Breastfeeding: none, < } 3 \text { months, < } 6 \text { months, } \\
\text { and 6+ months } \\
\text { - Maternal BMI } \\
\text { - Maternal age (years) } \\
\text { - Antenatal smoking: average number of } \\
\text { cigarettes smoked daily during pregnancy } \\
\text { - Alcohol consumption during pregnancy: } \\
\text { quantity consumed within a week } \\
\text { - Maternal nationality: Irish, UK, other European } \\
\text { Union, African or other. }\end{array}$ \\
\hline $\begin{array}{l}\text { a. Moraeus (2012) } \\
\text { b. Sweden } \\
\text { c. } 7\end{array}$ & $\begin{array}{l}\text { To examine the } \\
\text { influences of societal } \\
\text { and individual } \\
\text { characteristics of } \\
\text { children and their } \\
\text { parents, on the } \\
\text { prevalence of } \\
\text { overweight and } \\
\text { obesity. }\end{array}$ & $\begin{array}{l}\text { d. } 3636 \\
\text { e. } 7-9 \text { years } \\
\text { f. Nationally representative sample of } \\
\text { school children in Sweden } \\
\text { g. Cross-sectional } \\
\text { h. Regression }\end{array}$ & $\begin{array}{l}\text { IOTF } \\
\text { WHO }\end{array}$ & $\begin{array}{l}\text { Parent education } \\
>12 \text { years, } 10-12 \\
\text { years, } \leq 9 \text { years }\end{array}$ & $\begin{array}{l}\text { - TV watching: } \geq 2 \mathrm{hrs} / \text { day } \\
\text { - Breakfast on the day of study } \\
\text { - Parent BMI }\end{array}$ \\
\hline $\begin{array}{l}\text { a. Strauss (1999) } \\
\text { b. USA } \\
\text { c. } 6.5\end{array}$ & $\begin{array}{l}\text { To examine the role of } \\
\text { race, marital status, } \\
\text { maternal education, } \\
\text { and family income, as } \\
\text { well as standardised } \\
\text { measures of the home } \\
\text { environment in the } \\
\text { development of } \\
\text { childhood obesity }\end{array}$ & $\begin{array}{l}\text { d. } 2913 \\
\text { e. T1: 0-8 years, T2: 6-14 years } \\
\text { f. National Longitudinal Survey of Youth } \\
\text { (NLSY). Oversample of black and } \\
\text { Hispanic children, however data was } \\
\text { weighted to reflect a nationally } \\
\text { representative sample. } \\
\text { g. Cross-sectional and Longitudinal } \\
\text { h. Logistic regression }\end{array}$ & $\mathrm{CDC}$ & $\begin{array}{l}\text { Maternal education } \\
\text { Number of years } \\
\text { Household income } \\
\text { Low, middle and high } \\
\text { based on the } \\
\text { nationally weighted } \\
15^{\text {th }} \text { and } 85^{\text {th }} \\
\text { percentiles of the } \\
\text { total sample } \\
\text { Parental occupation } \\
\text { Coded according to } \\
\text { the } 1970 \text { US Census } \\
\text { Bureau codes }\end{array}$ & $\begin{array}{l}\text { - Child sex } \\
\text { - Child's initial weight-for-height z-score } \\
\text { - Ethnicity: African-American, Hispanic, Anglo- } \\
\text { American } \\
\text { - Maternal BMI } \\
\text { - Maternal marital status (\% single) } \\
\text { HOME-SF cognitive and emotional scores: } \\
\text { measure of the cognitive and emotional } \\
\text { stimulation in the household }\end{array}$ \\
\hline $\begin{array}{l}\text { a. First author (date } \\
\text { of publication) } \\
\text { b. Country }\end{array}$ & Main study aim & $\begin{array}{l}\text { d. Sample size } \\
\text { e. Sample mean age } \\
\text { f. Sample demographics }\end{array}$ & $\begin{array}{l}\text { COWOB } \\
\text { class. } \\
\text { system }\end{array}$ & $\begin{array}{l}\text { Socioeconomic status } \\
\text { proxy }\end{array}$ & Variables \\
\hline
\end{tabular}

This article is protected by copyright. All rights reserved. 


\begin{tabular}{|c|c|c|c|c|c|}
\hline c. Quality score & & $\begin{array}{l}\text { g. Study design } \\
\text { h. Statistical Analysis }\end{array}$ & & & \\
\hline $\begin{array}{l}\text { a. Van Den Berg } \\
\text { (2013) } \\
\text { b. Netherlands } \\
\text { c. } 6\end{array}$ & $\begin{array}{l}\text { The objective of this } \\
\text { study is first to } \\
\text { examine the relation of } \\
\text { maternal education } \\
\text { and growth velocity } \\
\text { during the first year of } \\
\text { life and early childhood } \\
\text { (1-5 years). }\end{array}$ & $\begin{array}{l}\text { d. } 1684 \\
\text { e. 1-5 years } \\
\text { f. Dutch ethnicity population-based } \\
\text { cohort study - Amsterdam Born } \\
\text { Children and their Development Study } \\
\text { g. Longitudinal } \\
\text { h. Regression and path analysis }\end{array}$ & $\begin{array}{l}\text { Dutch } \\
\text { reference } \\
\text { standards }\end{array}$ & $\begin{array}{l}\text { Maternal education } \\
<6 \text { years, } 6-10 \text { years, } \\
>10 \text { years }\end{array}$ & $\begin{array}{l}\text { - Child's birth weight } \\
\text { - Introduction of solid foods: <4 months, 4-6 } \\
\text { months, >6 months } \\
\text { - Smoking during pregnancy } \\
\text { - Breastfeeding duration: }<1 \text { month, 1-3 months, } \\
\text { 3-6 months, }>6 \text { months } \\
\text { - Maternal BMI } \\
\text { - Maternal age } \\
\text { - }\end{array}$ \\
\hline $\begin{array}{l}\text { a. Veldhuis (2013) } \\
\text { b. Netherlands } \\
\text { c. } 6.5\end{array}$ & $\begin{array}{l}\text { To examine the } \\
\text { association between } \\
\text { overweight and SES } \\
\text { among } 5 \text { year old } \\
\text { children }\end{array}$ & $\begin{array}{l}\text { d. } 5582 \\
\text { e. } 5 \text { years old } \\
\text { f. Ethnically homogenous group "Dutch" } \\
\text { ethnicity. } \\
\text { g. Cross-sectional } \\
\text { h. Multinomial logistic regression. (A } \\
\text { percentage change of }>5 \% \text { in ORs is } \\
\text { considered relevant for an educational } \\
\text { level subgroup.) }\end{array}$ & IOTF & $\begin{array}{l}\text { Maternal education } \\
\text { Low }=<\text { high school } \\
\text { Middle }=\text { completed } \\
\text { high school } \\
\text { High }=\geq \text { university }\end{array}$ & $\begin{array}{l}\text { - Child TV watching: } \leq 2 \mathrm{hrs} / \text { day vs. }>2 \mathrm{hrs} / \text { day } \\
\text { - Breakfast consumption: daily, }<7 \text { days/week } \\
\text { - Employment status: full-time, part-time or not } \\
\text { employed } \\
\text { - Single parenting: Two-parent families, single- } \\
\text { parent family or otherwise specified } \\
\text { - Maternal weight status: no overweight, } \\
\text { overweight and obese } \\
\text { - Maternal TV watching: } \leq 2 \mathrm{hrs} / \text { day vs. } \\
>2 \mathrm{hrs} / \text { day }\end{array}$ \\
\hline $\begin{array}{l}\text { a. Waters (2008) } \\
\text { b. Australia } \\
\text { c. } 5\end{array}$ & $\begin{array}{l}\text { To examine the } \\
\text { relationship between } \\
\text { overweight/obesity in } \\
\text { children, } \\
\text { socioeconomic status } \\
\text { and ethnicity/cultural } \\
\text { background. }\end{array}$ & $\begin{array}{l}\text { d. } 2685 \\
\text { e. } 4-13 \text { years } \\
\text { f. } 48.3 \% \text { had a parent born overseas } \\
\text { g. Cross-sectional } \\
\text { h. Logistic regression }\end{array}$ & $\begin{array}{l}\text { CDC } \\
\text { IOTF }\end{array}$ & $\begin{array}{l}\text { Parent education } \\
\leq \text { Grade } 10,11 / 12 \text { or } \\
\text { technical qualification, } \\
\text { or university }\end{array}$ & $\begin{array}{l}\text { - Parent BMI } \\
\text { - Ethnicity: Country/Area of birth }\end{array}$ \\
\hline $\begin{array}{l}\text { a. Wehrly (2014) } \\
\text { b. USA } \\
\text { c. } 6.5\end{array}$ & $\begin{array}{l}\text { To explore the } \\
\text { relationship between } \\
\text { measures of parental } \\
\text { control in child feeding } \\
\text { and child body } \\
\text { composition }\end{array}$ & $\begin{array}{l}\text { d. } 243 \\
\text { e. } 4.8 \text { years } \\
\text { f. The majority of parents reported a } \\
\text { monthly household income less than } \\
\$ 3000(49.8 \%) \text { and were of White-non } \\
\text { Hispanic background }(44.6 \%) \\
\text { g. Cross-sectional } \\
\text { h. Hierarchical multiple regression }\end{array}$ & CDC & $\begin{array}{l}\text { Monthly household } \\
\text { income } \\
\text { Above or below the } \\
\text { poverty line according } \\
\text { to the U.S. } \\
\text { Department of Human } \\
\text { Health and Human } \\
\text { services guidelines }\end{array}$ & $\begin{array}{l}\text { - Parental feeding style: pressure to eat and } \\
\text { restriction subscales from the Child Feeding } \\
\text { Questionnaire }\end{array}$ \\
\hline
\end{tabular}

This article is protected by copyright. All rights reserved. 


\begin{tabular}{|c|c|c|c|c|c|}
\hline \multicolumn{6}{|c|}{ Eleven studies investigating potential interaction effects } \\
\hline $\begin{array}{l}\text { a. First author (date } \\
\text { of publication) } \\
\text { b. Country } \\
\text { c. Quality score }\end{array}$ & Main study aim & $\begin{array}{l}\text { d. Sample size } \\
\text { e. Sample mean age } \\
\text { f. Sample demographics } \\
\text { g. Study design } \\
\text { h. Statistical Analysis }\end{array}$ & $\begin{array}{l}\text { COWOB } \\
\text { Class. } \\
\text { System }\end{array}$ & $\begin{array}{l}\text { Socioeconomic status } \\
\text { indicator } / \mathrm{s}\end{array}$ & Variables \\
\hline $\begin{array}{l}\text { a. Anderson (2003) } \\
\text { b. USA } \\
\text { c. } 8\end{array}$ & $\begin{array}{l}\text { To determine whether } \\
\text { a causal relationship } \\
\text { exists between } \\
\text { maternal employment } \\
\text { and childhood weight } \\
\text { problems. }\end{array}$ & $\begin{array}{l}\text { d. } 6283 \\
\text { e. 3-11 years (stratified into 3-5 and 6-11 } \\
\text { years) } \\
\text { f. National Longitudinal Survey of Youth } \\
\text { (NLSY) } \\
\text { g. Longitudinal } \\
\text { h. Econometric techniques }\end{array}$ & CDC & $\begin{array}{l}\text { Household income } \\
\text { Income quartiles since } \\
\text { birth } \\
\text { Maternal education } \\
\text { Less than high school, } \\
\text { high school or }>\text { some } \\
\text { college }\end{array}$ & $\begin{array}{l}\text { - Mother's employment: Never worked, mother } \\
\text { worked }<35 \mathrm{hrs} / \text { week since birth, mother } \\
\text { worked } \geq 35 \mathrm{hrs} / \text { week since birth }\end{array}$ \\
\hline $\begin{array}{l}\text { a. Balistreri (2011) } \\
\text { b. USA } \\
\text { c. } 8.5 \\
\text { (Also reported in } \\
\text { mediation table) }\end{array}$ & $\begin{array}{l}\text { To identify trajectories } \\
\text { of childhood } \\
\text { overweight, and to } \\
\text { measure the } \\
\text { association between } \\
\text { social/economic } \\
\text { factors with trajectory } \\
\text { membership. }\end{array}$ & $\begin{array}{l}\text { d. 13,970 } \\
\text { e. T1: Kindergarten T2: First grade T3: } \\
\text { Third grade T4: Fifth grade and T5: } \\
\text { Eigth grade } \\
\text { f. Early Childhood Longitudinal Study- } \\
\text { Kindergarten Cohort (ECLS-K). } 25 \% \\
\text { come from an immigrant family. } 89 \% \text { of } \\
\text { children had one parent with at least } \\
\text { high school degree. } \\
\text { g. Longitudinal } \\
\text { h. Mixture Models identified } 3 \\
\text { trajectories: 'Normal weight', 'Gradual } \\
\text { onset', 'Always' overweight' } \\
\text { Multinomial logistic regression }\end{array}$ & CDC & $\begin{array}{l}\text { Parental education } \\
\text { No high school, high } \\
\text { school degree, some } \\
\text { college or college } \\
\text { Annual household } \\
\text { income at } \mathrm{T} 1\end{array}$ & - Sex of child \\
\hline $\begin{array}{l}\text { a. First author (date } \\
\text { of publication) } \\
\text { b. Country } \\
\text { c. Quality score }\end{array}$ & Main study aim & $\begin{array}{l}\text { d. Sample size } \\
\text { e. Sample mean age } \\
\text { f. Sample demographics } \\
\text { g. Study design } \\
\text { h. Statistical Analysis }\end{array}$ & $\begin{array}{l}\text { COWOB } \\
\text { Class. } \\
\text { System }\end{array}$ & $\begin{array}{l}\text { Socioeconomic status } \\
\text { proxy }\end{array}$ & Variables \\
\hline $\begin{array}{l}\text { a. Hawkins (2008) } \\
\text { b. UK } \\
\text { c. } 8\end{array}$ & $\begin{array}{l}\text { To examine the } \\
\text { relationship between } \\
\text { maternal employment } \\
\text { and childhood } \\
\text { overweight }\end{array}$ & $\begin{array}{l}\text { d. } 13,113 \\
\text { e. } 3 \text { years old } \\
\text { f. } 89 \% \text { white mothers, } 31 \% \text { in managerial } \\
\text { or professional occupations, and } 14 \% \\
\text { were single mothers } \\
\text { g. Cross-sectional } \\
\text { h. Logistic regression }\end{array}$ & IOTF & $\begin{array}{l}\text { Maternal Socio } \\
\text { economic } \\
\text { circumstances: Office } \\
\text { for National Statistics } \\
\text { Maternal Education } \\
\text { Highest academic }\end{array}$ & $\begin{array}{l}\text { - Maternal employment hours: average hours } \\
\text { per week) }\end{array}$ \\
\hline
\end{tabular}

This article is protected by copyright. All rights reserved. 


\begin{tabular}{|c|c|c|c|c|c|}
\hline 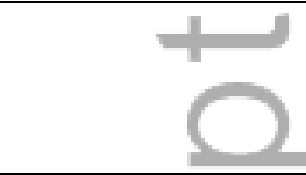 & & & & $\begin{array}{l}\text { qualification attained } \\
\text { Household Income } \\
\text { reported in bands }\end{array}$ & \\
\hline $\begin{array}{l}\text { a. Kakinami (2015) } \\
\text { b. Canada } \\
\text { c. } 8\end{array}$ & $\begin{array}{l}\text { To assess the effect } \\
\text { of parenting style on } \\
\text { the risk of childhood } \\
\text { obesity, and to } \\
\text { determine whether } \\
\text { poverty was a } \\
\text { moderator of the } \\
\text { association. }\end{array}$ & $\begin{array}{l}\text { d. } 37,577 \\
\text { e. 2-11 years (stratified into 2-5 and 6-11) } \\
\text { f. Cross-sectional } \\
\text { g. National Longitudinal Survey of Youth } \\
\text { (NLSY) } \\
\text { h. Logistic regression }\end{array}$ & WHO & $\begin{array}{l}\text { Household income } \\
\text { Poverty defined as } \\
\text { annual household } \\
\text { income below the } \\
\text { Statistics Canada cut- } \\
\text { off }\end{array}$ & $\begin{array}{l}\text { - Parenting style: Authoritative (responsive and } \\
\text { demanding), Authoritarian (not responsive but } \\
\text { demanding), Permissive (responsive but not } \\
\text { demanding) and Negligent (not responsive and } \\
\text { not demanding) }\end{array}$ \\
\hline $\begin{array}{l}\text { a. Martinson (2012) } \\
\text { b. USA \& UK } \\
\text { c. } 7\end{array}$ & $\begin{array}{l}\text { To compare obesity } \\
\text { between children of } \\
\text { native and foreign- } \\
\text { born mothers. }\end{array}$ & $\begin{array}{l}\text { d. } 9206 \\
\text { e. USA- T1:1 year, T2:3 years, T3: } 5 \text { years } \\
\text { \& } 9 \text { years } \\
\text { UK- T1: } 3 \text { years, T2: } 5 \text { years \& T3: } 7 \\
\text { years } \\
\text { f. Fragile Families and Child Wellbeing } \\
\text { Study (FFS) in USA and Millennium } \\
\text { Cohort Study (MCS) in UK -oversample } \\
\text { of ethnic minorities. } \\
\text { g. Cross-sectional \& Longitudinal } \\
\text { h. Multivariate logistic regression }\end{array}$ & CDC & $\begin{array}{l}\text { Maternal Education } \\
\text { High (some university) } \\
\text { or low (no university) } \\
\text { Low household } \\
\text { income Bottom } 30 \\
\text { percent of the income } \\
\text { distribution adjusted } \\
\text { for family size }\end{array}$ & $\begin{array}{l}\text { - Ethnicity: Mother's birthplace Hispanic, } \\
\text { African-American, White-American, Asian, } \\
\text { Caribbean and African } \\
\text { In the US, native-born black and Hispanic } \\
\text { mothers are more likely to be obese than } \\
\text { native-born white mothers. In England, there is } \\
\text { less variation in maternal obesity }\end{array}$ \\
\hline $\begin{array}{l}\text { a. First author (date } \\
\text { of publication) } \\
\text { b. Country } \\
\text { c. Quality score }\end{array}$ & Main study aim & $\begin{array}{l}\text { d. Sample size } \\
\text { e. Sample mean age } \\
\text { f. Sample demographics } \\
\text { g. Study design } \\
\text { h. Statistical Analysis }\end{array}$ & $\begin{array}{l}\text { COWOB } \\
\text { Class. } \\
\text { System }\end{array}$ & $\begin{array}{l}\text { Socioeconomic status } \\
\text { proxy }\end{array}$ & Variables \\
\hline $\begin{array}{l}\text { a. Morrissey (2014) } \\
\text { b. USA } \\
\text { c. } 5.5\end{array}$ & $\begin{array}{l}\text { To examine whether } \\
\text { the association } \\
\text { between maternal } \\
\text { depressive symptoms } \\
\text { and child obesity is } \\
\text { moderated by parent } \\
\text { education level }\end{array}$ & $\begin{array}{l}\text { d. } 6500 \\
\text { e. T1: } 9 \text { months, T2: } 2 \text { years, T3: } 4 \text { years, } \\
\text { T4: } 5.5 \text { years } \\
\text { f. Early Childhood Longitudinal Study- } \\
\text { Birth Cohort (ECLS-B) } \\
\text { g. Longitudinal } \\
\text { h. Linear probability modelling }\end{array}$ & $\mathrm{CDC}$ & $\begin{array}{l}\text { Parental education at } \\
\text { T1 Neither parent } \\
\text { graduated high school, } \\
\text { at least one parent } \\
\text { has a high school } \\
\text { degree, at least one } \\
\text { parent graduated } \\
\text { from college }\end{array}$ & $\begin{array}{l}\text { - Maternal depressive symptoms (modified } \\
\text { version of the Centre for Epidemiologic Studies } \\
\text { Depression Scale at each wave) }\end{array}$ \\
\hline $\begin{array}{l}\text { a. Novotny (2013 } \\
\text { b. Hawaii (USA) }\end{array}$ & $\begin{array}{l}\text { To examine the } \\
\text { prevalence of }\end{array}$ & $\begin{array}{l}\text { d. } 8839 \\
\text { e. } 6 \text { years }\end{array}$ & CDC & $\begin{array}{l}\text { Neighbourhood SES } \\
\text { Neighbourhood }\end{array}$ & $\begin{array}{l}\text { - Ethnicity: White, Asian, Filipino, native } \\
\text { Hawaiian, Samoan, Hawaiian-Asian, other }\end{array}$ \\
\hline
\end{tabular}

This article is protected by copyright. All rights reserved. 


\begin{tabular}{|c|c|c|c|c|c|}
\hline c. 7.5 & $\begin{array}{l}\text { childhood overweight } \\
\text { and obesity in } 5 \text { - } 8 \\
\text { year olds, with } \\
\text { adjustment for } \\
\text { important covariates. }\end{array}$ & $\begin{array}{l}\text { f. Nationally representative sample of } \\
\text { Hawaiian children and their families. } \\
13.6 \% \text { white, } 9.4 \% \text { less than university } \\
\text { educated. } \\
\text { g. Cross-sectional } \\
\text { h. Mixed Logistic Models }\end{array}$ & & $\begin{array}{l}\text { education level based } \\
\text { on } 2000 \text { Census. High } \\
\text { school or less, some } \\
\text { college, associate } \\
\text { degree or greater than } \\
\text { associate degree }\end{array}$ & mixed, other \\
\hline $\begin{array}{l}\text { a. Rodenburg (2011) } \\
\text { b. Netherlands } \\
\text { c. } 6\end{array}$ & $\begin{array}{l}\text { To explore whether the } \\
\text { potential association } \\
\text { between parenting and } \\
\text { child weight is } \\
\text { moderated by socio- } \\
\text { demographic } \\
\text { variables }\end{array}$ & $\begin{array}{l}\text { d. } 1665 \\
\text { e. } 8 \text { years } \\
\text { f. IVO Nutrition and Physical Activity } \\
\text { Child cohort (INPACT study) } \\
\text { g. Cross-sectional } \\
\text { h. Linear regression }\end{array}$ & $\begin{array}{l}1997 \\
\text { National } \\
\text { Growth } \\
\text { Study }\end{array}$ & $\begin{array}{l}\text { Parental education } \\
\text { Low (primary school } \\
\text { and lower secondary), } \\
\text { medium (higher } \\
\text { secondary and } \\
\text { university prep), or } \\
\text { high (higher } \\
\text { vocational education } \\
\text { and university) }\end{array}$ & $\begin{array}{l}\text { - Parenting styles ( } 22 \text { item instrument by } \\
\text { Steinberg et al.): Authoritative, Permissive, } \\
\text { Authoritarian, Rejecting (low support, low } \\
\text { behavioural control, high psychological control), } \\
\text { and Neglecting. }\end{array}$ \\
\hline $\begin{array}{l}\text { a. Semmler (2009) } \\
\text { b. UK } \\
\text { c. } 4.5\end{array}$ & $\begin{array}{l}\text { To test if SES } \\
\text { moderates the } \\
\text { association between } \\
\text { parental weight and } \\
\text { changes in BMI from } \\
\text { childhood to early } \\
\text { adolescence. }\end{array}$ & $\begin{array}{l}\text { d. } 333 \\
\text { e. T1: } 2 \text { years, T2: } 4 \text { years, T3: } 11 \text { years } \\
\text { f. Twin children of families with obese } \\
\text { parents and socio-demographically } \\
\text { matched families with normal-weight } \\
\text { parents } \\
\text { g. Longitudinal } \\
\text { h. Analysis of variance, controlling for } \\
\text { gender, age at follow-up, zygosity, and } \\
\text { clustering in twin pairs. }\end{array}$ & $\begin{array}{l}1990 \\
\text { British } \\
\text { Norms }\end{array}$ & $\begin{array}{l}\text { Maternal education: } \\
\text { lower SES (GSCE or } \\
\text { less) vs. higher SES (A } \\
\text { level or above) }\end{array}$ & - Mother's measured BMI \\
\hline $\begin{array}{l}\text { a. First author (date } \\
\text { of publication) } \\
\text { b. Country } \\
\text { c. Quality score }\end{array}$ & Main study aim & $\begin{array}{l}\text { d. Sample size } \\
\text { e. Sample mean age } \\
\text { f. Sample demographics } \\
\text { g. Study design } \\
\text { h. Statistical Analysis }\end{array}$ & $\begin{array}{l}\text { COWOB } \\
\text { Class. } \\
\text { System }\end{array}$ & $\begin{array}{l}\text { Socioeconomic status } \\
\text { proxy }\end{array}$ & Variables \\
\hline $\begin{array}{l}\text { a. Topham (2009) } \\
\text { b. USA } \\
\text { c. } 5\end{array}$ & $\begin{array}{l}\text { To test the moderating } \\
\text { influence of two risk } \\
\text { factors, maternal } \\
\text { depression and SES on } \\
\text { the ass bw } \\
\text { authoritarian and } \\
\text { permissive parenting } \\
\text { styles and child obesity }\end{array}$ & $\begin{array}{l}\text { d. } 176 \\
\text { e. } 6.85 \text { years } \\
\text { f. } 78 \% \text { white mothers, } 15.4 \% \text { less than } \\
\text { college educated, } 13.6 \% \text { were single } \\
\text { mothers } \\
\text { g. Cross-sectional } \\
\text { h. Multiple Logistic Regression }\end{array}$ & $\mathrm{CDC}$ & $\begin{array}{l}\text { Household income } \\
\text { Four-factor } \\
\text { Hollingshead index } \\
\text { based on Parental } \\
\text { education and } \\
\text { Maternal Occupation }\end{array}$ & $\begin{array}{l}\text { - Parenting style (Parenting Styles and } \\
\text { Dimensions Questionnaire) } \\
\text { Authoritarian } \\
\text { Permissive }\end{array}$ \\
\hline a. Lane (2013) & To examine the impact & d. 917 & CDC & Household Income: & - Parenting style (Method prescribed by Rhee et \\
\hline
\end{tabular}

This article is protected by copyright. All rights reserved. 


\begin{tabular}{|c|c|c|c|c|}
\hline $\begin{array}{l}\text { b. USA } \\
\text { c. } 6.5\end{array}$ & $\begin{array}{l}\text { of socio economic } \\
\text { status and } \\
\text { psychosocial predictors } \\
\text { on trajectories of } \\
\text { childhood adiposity. }\end{array}$ & $\begin{array}{l}\text { e. } 24 \text { months to } 11 \text { years old } \\
\text { f. Diverse study sample: } 24 \% \text { minorities, } \\
11 \% \text { mothers with < high school } \\
\text { education and } 14 \% \text { single mothers } \\
\text { g. Longitudinal } \\
\text { h. Growth mixture models }\end{array}$ & $\begin{array}{l}\text { Not adjusted for costs } \\
\text { of living based on } \\
\text { geographical location } \\
\text { or family size }\end{array}$ & $\begin{array}{l}\text { al.): } \\
\text { Permissive, Authoritative, Authoritarian and } \\
\text { Neglectful }\end{array}$ \\
\hline
\end{tabular}

$=$ World Health Organisation standards.

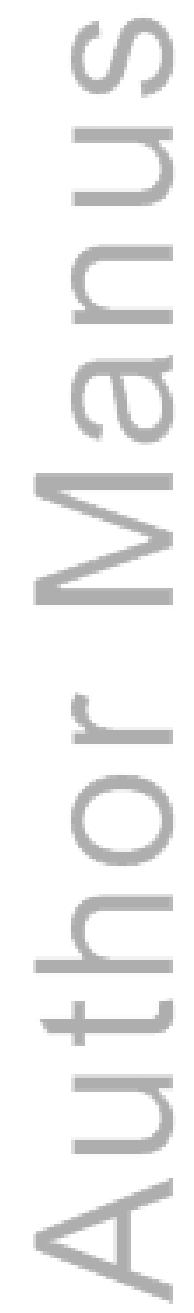


Table 3. Child-system factors identified within multivariate analyses of the SES-COWOB relationship

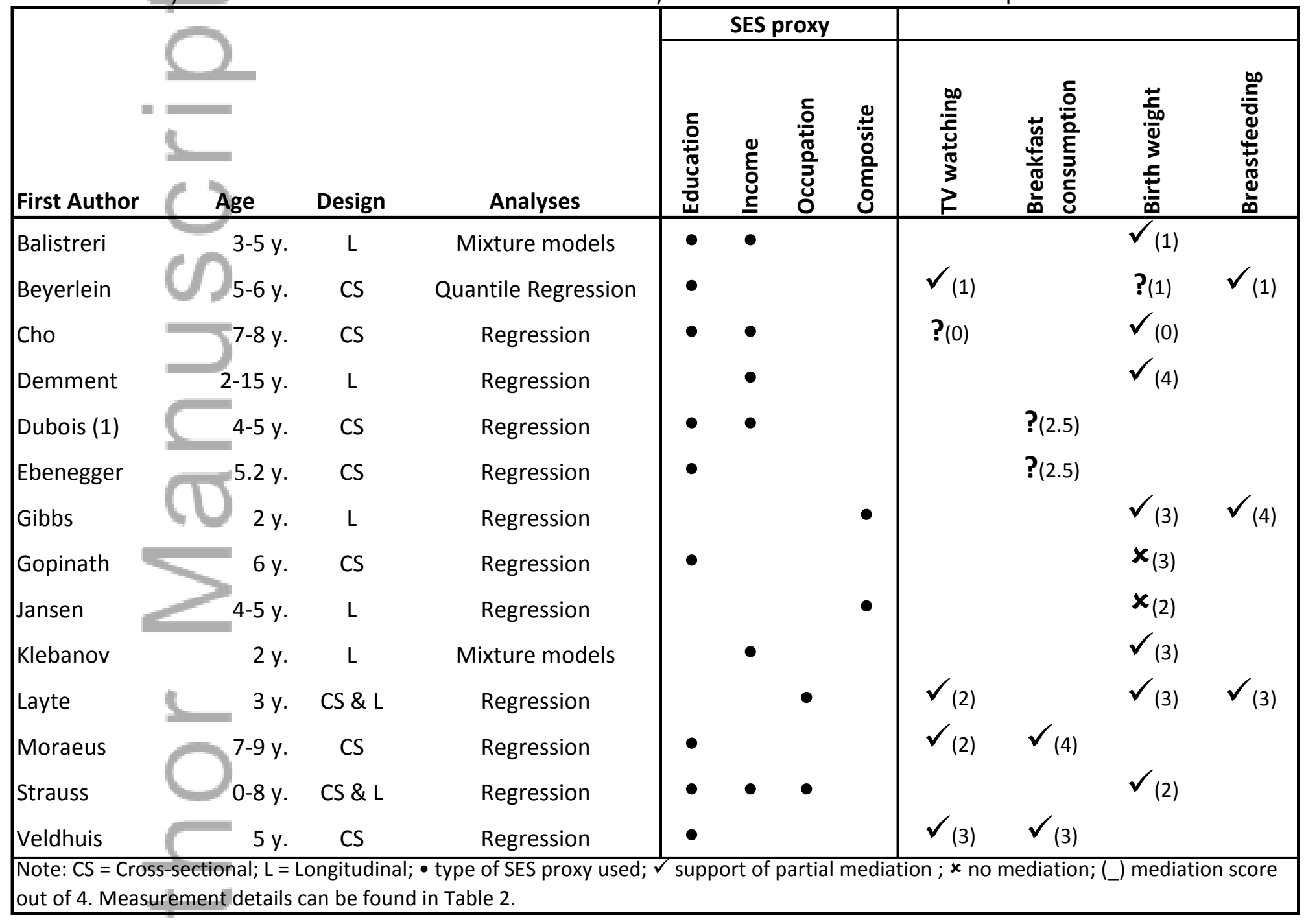

This article is protected by copyright. All rights reserved. 
Table 4. Parent- and houshold-system factors identified within multivariate analyses of the SES-COWOB relationship

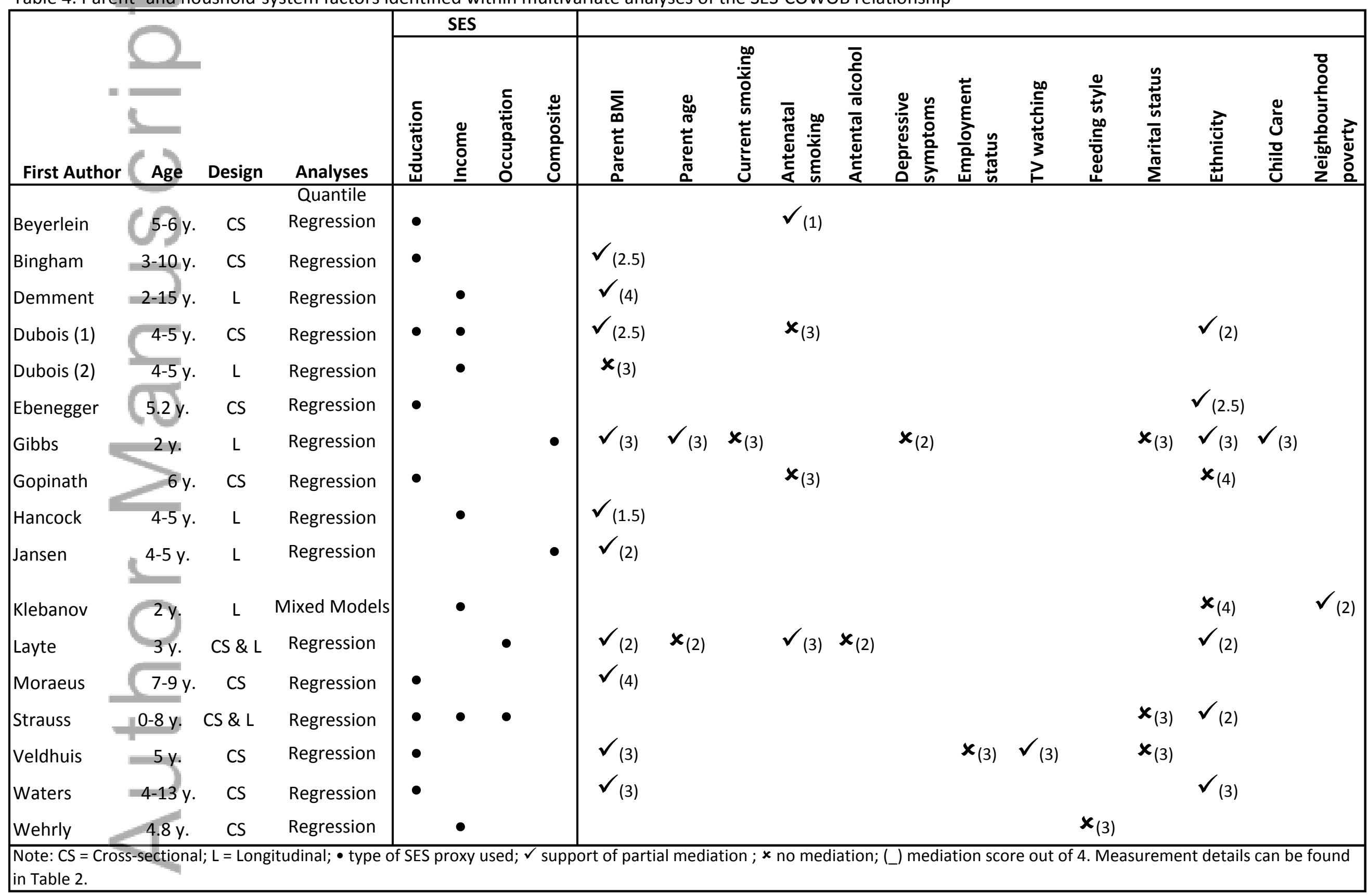

This article is protected by copyright. All rights reserved. 
Supplementary Table 1. Assessment of quality of evidence

\begin{tabular}{|c|c|c|c|c|c|c|c|c|c|c|c|c|c|c|c|c|c|c|c|c|c|c|c|c|c|c|c|c|c|c|}
\hline$=$ & 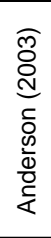 & 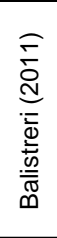 & 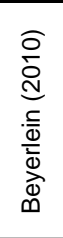 & 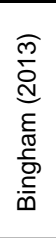 & $\begin{array}{l}\text { के } \\
\text { d̦ } \\
\frac{0}{u}\end{array}$ & 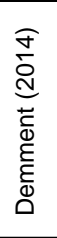 & 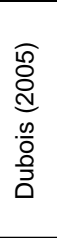 & $\begin{array}{l}\widehat{Q} \\
\stackrel{0}{1} \\
. \frac{0}{0} \\
\frac{0}{0}\end{array}$ & 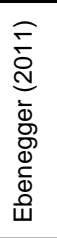 & 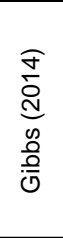 & 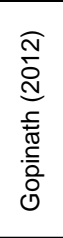 & 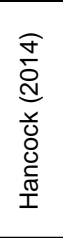 & 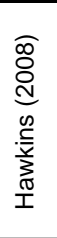 & 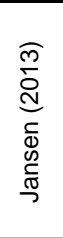 & 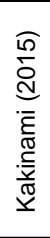 & 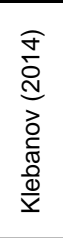 & 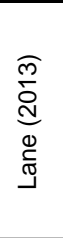 & 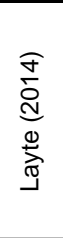 & 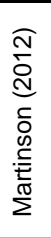 & 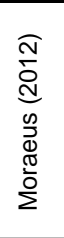 & 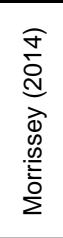 & 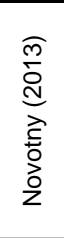 & 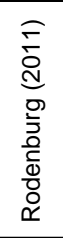 & 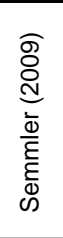 & 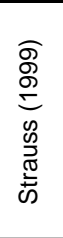 & 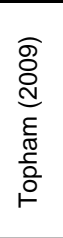 & 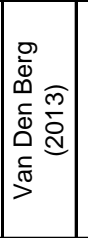 & 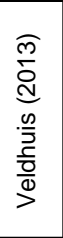 & 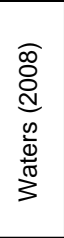 & 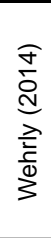 \\
\hline $\begin{array}{l}\text { Sample size: } 1 \text { point for } n \geq 10,000,0.5 \\
\text { point for } 1,000 \leq n \leq 10,000 \text { or } 0 \text { point if } \\
n<1000 \text { or not reported }\end{array}$ & 1 & 1 & 0.5 & 0.5 & 0 & 0 & 0.5 & 0.5 & 0 & 0.5 & 0.5 & 0.5 & 1 & 0.5 & 1 & 0 & 0.5 & 1 & 1 & 0.5 & 0.5 & 0.5 & 0.5 & 0 & 0.5 & 0 & 0.5 & 0.5 & 0.5 & 0 \\
\hline $\begin{array}{l}\text { Response rate: } 1 \text { point if response rate } \\
\geq 70 \%, 0.5 \text { if response rate } 50-70 \% \text { or } 0 \\
\text { if response rate }<50 \% / \text { not reported }\end{array}$ & 1 & 0.5 & 1 & 0.5 & 0.5 & 0 & 1 & 0 & 1 & 1 & 1 & 0.5 & 1 & 0.5 & 1 & 1 & 0 & 0.5 & 0 & 0.5 & 0 & 1 & 0.5 & 0 & 1 & 0 & 0.5 & 0.5 & 0 & 0 \\
\hline $\begin{array}{l}\text { Representative study population: } 1 \\
\text { point if clearly stated, } 0.5 \text { point if clearly } \\
\text { stated cohort but not necessarily } \\
\text { externally valid to nation or } 0 \text { points if } \\
\text { other/ not reported }\end{array}$ & 1 & 1 & 1 & 1 & 0.5 & 0.5 & 1 & 1 & 0.5 & 1 & 1 & 1 & 1 & 1 & 1 & 0.5 & 1 & 1 & 1 & 1 & 1 & 1 & 1 & 0.5 & 1 & 0 & 1 & 0.5 & 0.5 & 0.5 \\
\hline $\begin{array}{l}\text { Weight measured by a trained } \\
\text { person: } 1 \text { point or } 0 \text { point if reported by } \\
\text { parents }\end{array}$ & 1 & 1 & 1 & 1 & 1 & 1 & 1 & 1 & 1 & 1 & 1 & 1 & 1 & 1 & 1 & 1 & 1 & 1 & 1 & 1 & 1 & 1 & 1 & 1 & 1 & 1 & 1 & 1 & 1 & 1 \\
\hline $\begin{array}{l}\text { BMI classification: } 1 \text { point if a } \\
\text { standardised measure was used or } 0 \\
\text { point for non-standardised country- } \\
\text { specific BMI charts). }\end{array}$ & 1 & 1 & 1 & 1 & 1 & 1 & 1 & 1 & 0 & 1 & 1 & 1 & 1 & 1 & 1 & 0 & 1 & 1 & 1 & 1 & 1 & 1 & 0 & 0 & 1 & 1 & 0 & 1 & 1 & 1 \\
\hline $\begin{array}{l}\text { Statistical test conducted: } 1 \text { point if } \\
\text { analysis allowed for assessment of } \\
\text { statistically significant associations or } 0 \\
\text { points otherwise }\end{array}$ & 1 & 1 & 1 & 1 & 1 & 1 & 1 & 1 & 1 & 1 & 1 & 1 & 1 & 1 & 1 & 1 & 1 & 1 & 1 & 1 & 1 & 1 & 1 & 1 & 1 & 1 & 1 & 1 & 1 & 1 \\
\hline $\begin{array}{l}\text { Controlling for confounders: } 1 \text { point if } \\
\text { controlled for any confounders or } 0 \text { if } \\
\text { only did bivariate analysis }\end{array}$ & 1 & 1 & 1 & 1 & 1 & 1 & 1 & 1 & 1 & 1 & 1 & 1 & 1 & 1 & 1 & 1 & 1 & 1 & 1 & 1 & 1 & 1 & 1 & 1 & 1 & 1 & 1 & 1 & 1 & 1 \\
\hline $\begin{array}{l}\text { Specific age group or stratifying } \\
\text { results by age group: } 1 \text { point if } \\
\text { stratified results or specifically stated } \\
\text { that a test had been done and age was } \\
\text { not an effect modifier in the population } \\
\text { studied or } 0 \text { points if did not discuss }\end{array}$ & 1 & 1 & 1 & 1 & 1 & 1 & 1 & 1 & 1 & 1 & 1 & 1 & 1 & 1 & 1 & 1 & 1 & 1 & 1 & 1 & 1 & 1 & 1 & 1 & 0 & 1 & 1 & 1 & 0 & 1 \\
\hline TOTAL & 8 & 7.5 & 7.5 & 7 & 6 & 5.5 & 7.5 & 6.5 & 5.5 & 7.5 & 7.5 & 7 & 8 & 7 & 8 & 5.5 & 6.5 & 7.5 & 7 & 7 & 6.5 & 7.5 & 6 & 4.5 & 6.5 & 5 & 6 & 6.5 & 5 & 5.5 \\
\hline
\end{tabular}

This article is protected by copyright. All rights reserved. 
Table 3. Child-system factors identified within multivariate analyses of the SES-COWOB relationship

\begin{tabular}{|c|c|c|c|c|c|c|c|c|c|c|c|}
\hline \multirow{2}{*}{ First Author } & \multirow{2}{*}{ 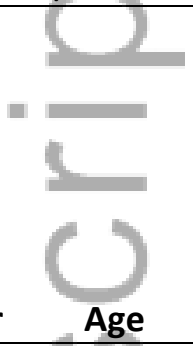 } & \multirow[b]{2}{*}{ Design } & \multirow[b]{2}{*}{ Analyses } & \multicolumn{4}{|c|}{ SES proxy } & \multirow[b]{2}{*}{ 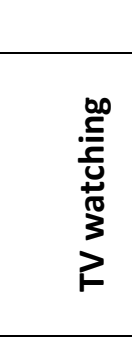 } & \multirow[b]{2}{*}{ 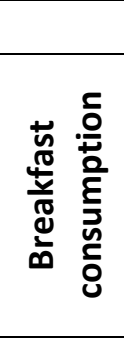 } & \multirow[b]{2}{*}{ 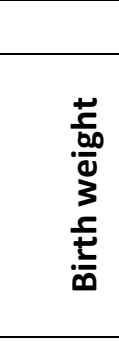 } & \multirow[b]{2}{*}{ 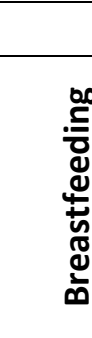 } \\
\hline & & & & 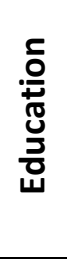 & $\begin{array}{l}\stackrel{\Xi}{\xi} \\
\text { ğ }\end{array}$ & 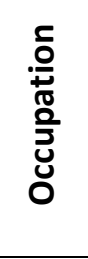 & 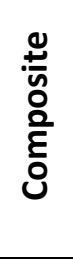 & & & & \\
\hline Balistreri & & $\mathrm{L}$ & Mixture models & & $\bullet$ & & & & & $\checkmark_{(1)}$ & \\
\hline Beyerlein & $5-6 y$. & CS & Quantile Regression & $\bullet$ & & & & $\checkmark_{(1)}$ & & $?(1)$ & $\checkmark_{(1)}$ \\
\hline Cho & $7-8 y$. & CS & Regression & $\bullet$ & $\bullet$ & & & $?(0)$ & & $\checkmark_{(0)}$ & \\
\hline Demment & $2-15 y$ & $\mathrm{~L}$ & Regression & & $\bullet$ & & & & & $\sqrt{(4)}$ & \\
\hline Dubois (1) & & CS & Regression & & $\bullet$ & & & & $?(2.5)$ & & \\
\hline Ebenegger & $5.2 \mathrm{y}$. & CS & Regression & $\bullet$ & & & & & $?(2.5)$ & & \\
\hline Gibbs & & $\mathrm{L}$ & Regression & & & & $\bullet$ & & & $\checkmark_{(3)}$ & $\checkmark_{(4)}$ \\
\hline Gopinath & $6 \mathrm{y}$. & $\mathrm{CS}$ & Regression & $\bullet$ & & & & & & $x_{(3)}$ & \\
\hline Jansen & $4-5 y$. & $\mathrm{L}$ & Regression & & & & $\bullet$ & & & $x_{(2)}$ & \\
\hline Klebanov & $2 y$. & $L$ & Mixture models & & $\bullet$ & & & & & $\checkmark_{(3)}$ & \\
\hline Layte & $3 y$. & CS \& L & Regression & & & $\bullet$ & & $\checkmark_{(2)}$ & & $\checkmark_{(3)}$ & $\checkmark_{(3)}$ \\
\hline Moraeus & $7-9 y$. & $\mathrm{CS}$ & Regression & $\bullet$ & & & & $\checkmark_{(2)}$ & $\checkmark_{(4)}$ & & \\
\hline Strauss & $0-8 \mathrm{y}$ & $C S \& L$ & Regression & & $\bullet$ & $\bullet$ & & & & $\checkmark_{(2)}$ & \\
\hline Veldhuis & $\begin{array}{l}-5 y . \\
\end{array}$ & CS & Regression & $\bullet$ & & & & $\checkmark_{(3)}$ & $\checkmark_{(3)}$ & & \\
\hline
\end{tabular}

This article is protected by copyright. All rights reserved. 


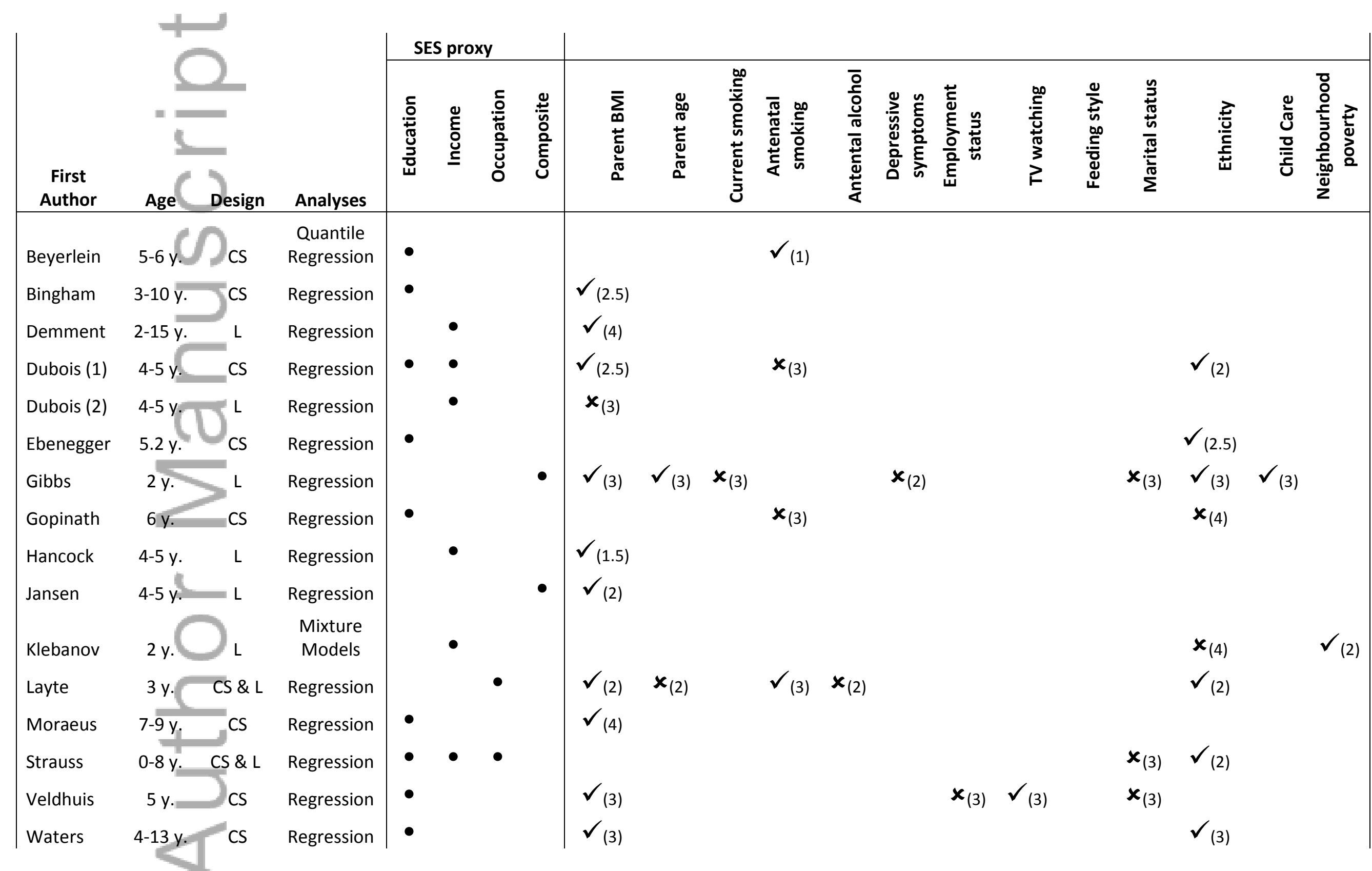

This article is protected by copyright. All rights reserved. 


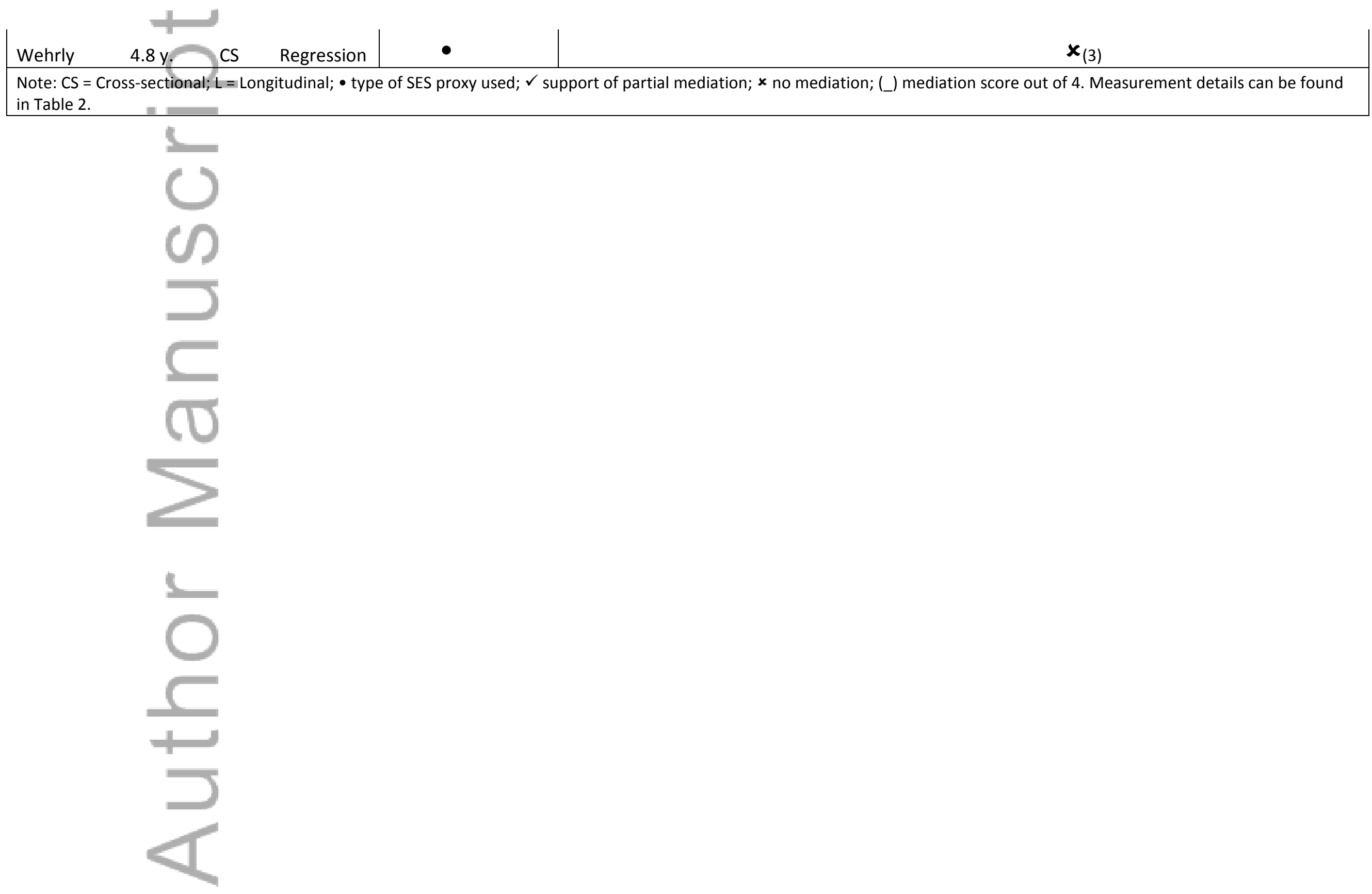

This article is protected by copyright. All rights reserved. 


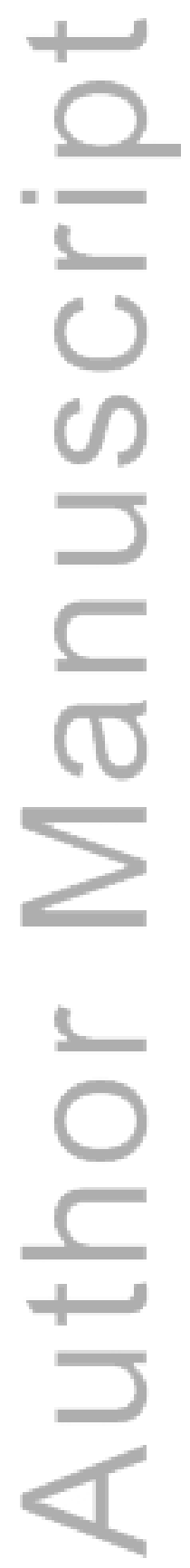

This article is protected by copyright. All rights reserved. 


\section{University Library}

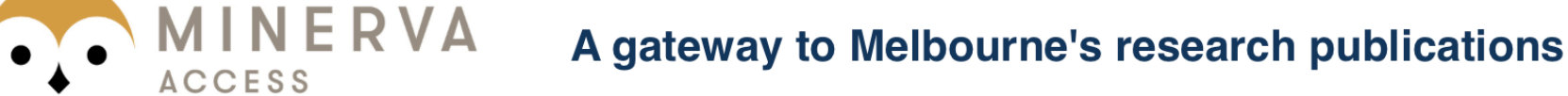

Minerva Access is the Institutional Repository of The University of Melbourne

Author/s:

Mech, P;Hooley, M;Skouteris, H;Williams, J

Title:

Parent-related mechanisms underlying the social gradient of childhood overweight and obesity: a systematic review

Date:

2016-09-01

Citation:

Mech, P., Hooley, M., Skouteris, H. \& Williams, J. (2016). Parent-related mechanisms underlying the social gradient of childhood overweight and obesity: a systematic review. CHILD CARE HEALTH AND DEVELOPMENT, 42 (5), pp.603-624. https://doi.org/10.1111/ cch.12356.

Persistent Link:

http://hdl.handle.net/11343/291424 